\title{
Partial Purification and Characterization of Antimicrobial Effects from Snake (Echis carinatus), Scorpion (Mesosobuthus epues) and Bee (Apis mellifera) venoms
}

\author{
Mahdi Babaie $^{1,2 *}$ (D), Aram Ghaem panah ${ }^{1}$, Zahra Mehrabi $^{3}$, Ali Mollaei ${ }^{4}$, Sima Khalilifard Borojeni ${ }^{4}$
}

1. Young Researchers and Elites Club, Science and Research Branch, Islamic Azad University, Tehran, Iran.

2. Reference Laboratory of Bovine Tuberculosis, Razi Vaccine and Serum Research Institute, Agricultural Research Education and Extension Organization (AREEO), Tehran, Iran.

3. Department of Biology, Faculty of sciences, Karaj Branch, Islamic Azad University, Karaj, Iran.

4. Department of Veterinary Aerobic Bacterial Vaccines, Razi Vaccine and Serum Research Institute, Agricultural Research, Education and Extension Organization (AREEO), Karaj, Iran

\section{ABSTRACT}

Background: Some venoms and their isolated compounds have been shown to have antibacterial properties. Snake, scorpion and bee venoms are a complex mixture of proteins such as phospholipase and melittin, which have an effect on bacterial growth inhibition. This study aimed to investigate of antibacterial effect of three different venoms against selected bacterial strains.

Materials \& Methods: Crude venoms obtained from snake (Echis carinatus), scorpion (Mesosobuthus epues) and bee (Apis mellifera) were selected. The crude venoms from these species was purified by using gel filtration chromatography and the molecular weights of the compounds in these venoms estimated by using SDS-PAGE. The approximate lethal dose values of venoms were determined. Antibacterial activity of venoms against Staphylococcus aureus, Bacillus subtilis, Pseudomonas aeruginosa and Escherichia coli were evaluated. Venoms and its isolated fractions and standard antibiotic were tested by using the disc diffusion method.

Results: E. carinatus crude venom and fraction 2 were effective against S. aureus and E. coli. M. eupeus crude venom and fraction 1 and 4 were effective against $B$. subtilis. A. mellifera crude venom demonstrated antibacterial activity against $E$. coli, S. aureus and Fraction 3 of this venom has an inhibition effect for E. coli and S. aureus.

Conclusion: Snake, scorpion and bee venoms inhibit the growth and survival of bacterial strains and that these venoms can be used as a complementary antimicrobial agent against pathogenic bacteria.

Keywords: Echis carinatus, Mesosobuthus epues, Apis mellifera, antibacterial activity, chromatography, LD $_{50}$

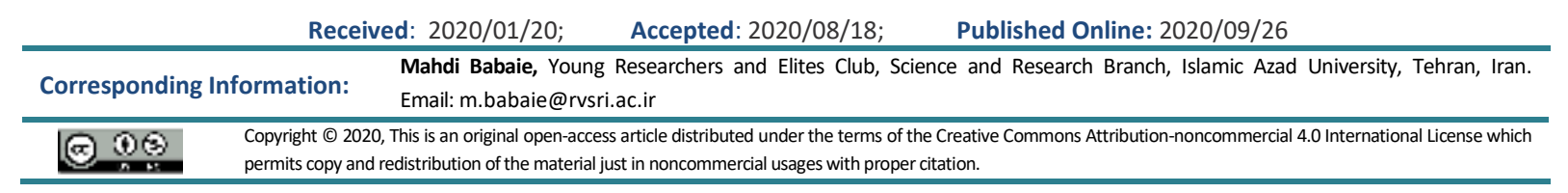

Use your device to scan and read the article online

Babaie M, Ghaem panah A, Mehrabi Z, Mollaei A. Partial purification and characterization of antimicrobial effects from snake (Echis carinatus), scorpion (Mesosobuthus epues) and bee (Apis mellifera) venoms. Iran J Med Microbiol. 2020; 14 (5) :460-477

Download citation: BibTeX | RIS | EndNote | Medlars | ProCite | Reference Manager | RefWorks
Send citation to:
Mendeley
2 zotero
RefWorks 


\section{Introduction}

Infectious diseases have increased in recent years. These diseases are caused by pathogens such as bacteria, viruses, etc. Due to the lack of useful and effective drugs for the treatment of infectious diseases, they have spread worldwide (1). Antibiotic treatment is currently used for bacterial infections. But nowadays, it has been found that the effectiveness of many antibiotics has diminished due to their overuse. This phenomenon is known as antibiotic resistance. Antibiotic resistance is a serious public health problem and this resistance is increasing in today's world. In 2014, the World Health Organization described drug resistance to antibiotics as a "major global threat." (2).

As antimicrobial resistance is spreading throughout the world, the discovery of new substances is mandatory to fight against it. This will cause researchers to conduct more studies on various natural resources in order to discover newer and more effective antibiotics (3). In fact, the vast diversity of bioactive molecules in nature has long inspired scientists in their search for potential therapeutic agents (4).

More recently, there has been a resurge in the use of antimicrobial peptides due to the decrease in the efficiency of common treatments. Antimicrobial peptides are able to target a broad spectrum of microbes with little resistance and can have a synergistic effect with antibiotics. Animal venom is thus a particularly promising source in this search for new antimicrobial compounds. Many antimicrobial peptides from the venom have shown high efficacy in vitro and in vivo, but challenges to overcome their host toxicity $(5,6)$, hemolytic activity (7-11), as well as the bioavailability and stability of these peptides are still present.

With more than 100,000 venomous animals, naturally occurring antimicrobial agents present in venomous species, thus hold promises for the development of novel therapeutic agents. Currently, only few antimicrobial agents are present on the market for tropical use (12).

Venoms from some animals, including snakes, scorpions, spiders, bees, etc. can be interesting and powerful alternatives to antibiotics (13). In venoms of these animals, bioactive proteins and peptides are found that have various useful pharmacological properties and are stored in large quantities (14).

One of the important reasons for the effectiveness or ineffectiveness of different animal venoms on various bacterial species is their mechanisms of action on the bacterial cell envelope. Bacterial cytoplasmic membrane is the primary target of the antibacterial peptides in venoms. Antibacterial peptides form channels in the bacterial cell membrane or disrupt phospholipid bilayers of bacterial membrane, thereby influencing its numerous functions that are necessary for the survival of the bacteria and thus cause bacterial cell death. As pointed out in some of these studies, some of the differences in the effects of these peptides stem from the differences in bacterial cell envelopes. Since these envelopes in Gram-positive bacteria consist of fewer layers compared to Gram-negative bacteria, antibacterial peptides must be more powerful in order to affect Gram-negative bacteria (15).

Today, many studies have been conducted using molecular methods on a variety of antimicrobial peptides and how they work (16-18).

The findings indicate that some of peptides present in the venom of these animals have antimicrobial properties and prevent the growth of pathogens. Antimicrobial peptides have been shown to inhibit the growth of many resistant pathogens. However, many antibiotics do not show such efficacy (19). They can be useful and valuable as pharmacological tools in drug research, as potential drug design templates, and as therapeutic agents (20).

Here we have characterized and investigated antimicrobial effect from Snake (Echis carinatus), scorpion (Mesosobuthus epues) and bee (Apis mellifera) venoms.

\section{Materials and Methods}

\section{Bacterial Strains}

Four clinical isolates of bacteria, including Staphylococcus aureus (ATCC 25923), Pseudomonas aeruginosa (ATCC 27853), Escherichia coli 0157:H7 (ATCC 25923), Bacillus subtilis (ATCC: 6633) were purchased from the China Center of Type Culture Collection (CCTCC).

\section{Experimental Animals}

Animal studies were performed in compliance with the regulations of Razi vaccine and serum research institute (RVSRI), and with generally accepted guidelines governing such works. For this aim, normal male mice, weighing between 25 and $30 \mathrm{~g}$ were injected with venoms and investigated.

\section{Other Materials and Equipment}

The following Equipment and materials were used for laboratory work; Millipore filter (Biofil $0.45 \mu \mathrm{m}, \mathrm{China}$ ), Centrifuge (Hermle Z513K, Germany), Freeze dryer (Christ alpha 1-4 Isc, Germany), UV spectrophotometer (UNICO SQ2800, USA), Electric heater (Electrothermal M105, England), Electrophoresis and protein markers (Bio-Rad, USA), Incubator (Memmert, Germany), Sephadex G-50 (Pharmacia, Sweden), and the Standard antibiotic gentamicin (Liofilchem S.r.1, Italy). Other reagents and chemicals were of analytical grade from Merck and Fluka. 


\section{Venoms Preparation}

Lyophilized crude venom of Echis carinatus (Lot No. V8250) and Apis mellifera (Lot No. V3375) were purchased (Sigma Aldrich, Germany). Crude venom of Mesobuthus eupeus scorpion was obtained by the electrical stimulation at the end of the tail $(128 \mathrm{~Hz}, 20$ V). After lyophilization, it was stored at $-20^{\circ} \mathrm{C}$. The freeze-dried venoms were dissolved in distilled water or a suitable buffer and then venom solutions were centrifuged at $12000 \mathrm{~g}$ for 4 mins and the supernatant was collected.

\section{Venoms Purification}

Lyophilized crude venoms (200 mg) were dissolved in $4 \mathrm{~mL}$ of $0.1 \mathrm{M}$ ammonium acetate buffer $(\mathrm{pH} 8.6)$ and the insoluble material was removed by centrifugation (12000 g, $4 \mathrm{~min}$ ) and filtration. Supernatant was applied to a column of sephadex G-50 $(2.5 \times 150 \mathrm{~cm})$ equilibrated with $0.1 \mathrm{M}$ ammonium acetate buffer $(\mathrm{pH} 8.6)$. The elution was carried out with the same buffer at a flow rate of 60 $\mathrm{mL} / \mathrm{h}$. Volumes of $10 \mathrm{~mL}$ were collected and each fraction was identified by UV spectrophotometer (280 nm), mixed and lyophilized (5).

\section{Venoms protein concentration}

Protein content in the crude venom was determined by Lowry (6) and Kjeldahl method with some modifications (21). Fourteen $\mathrm{mL}$ of distilled water and 2 $\mathrm{mL}$ of trichloroacetic acid ( $100 \% \mathrm{w} / \mathrm{v})$ was added to 5 $\mathrm{mL}$ of protein solution. The solution was mixed and allowed to stand for $5 \mathrm{~min}$ and then centrifuged for 10 $\min$ at $2000 \mathrm{~g}$. The supernatant liquid was discarded and the residue was dissolved in $0.5 \mathrm{~mL}$ of $10 \mathrm{~N} \mathrm{NaOH}$. Dissolved residue was adjusted to $25 \mathrm{~mL}$ with distilled water. About $0.9 \mathrm{~g}$ of $\mathrm{K}_{2} \mathrm{SO}_{4}, 0.1 \mathrm{~g}$ of $\mathrm{CuSO}_{4}$ and then 10 $\mathrm{mL}$ of dissolved residue was added to Kjeldahl flask. Then $7 \mathrm{~mL}$ of sulfuric acid $98 \%$ and $1 \mathrm{~mL}$ of $\mathrm{H}_{2} \mathrm{O}_{2} 30 \%$ was added. The flask was heated to about $80^{\circ} \mathrm{C}$ for $48 \mathrm{~h}$ using an electric heater. After $48 \mathrm{~h}$, the digested solution was cooled and about $10 \mathrm{~mL}$ of distilled water was added to the flask. The contents of the flask were poured into the Kjeldahl machine. Subsequently, 25-30 $\mathrm{mL}$ of $\mathrm{NaOH} 10 \mathrm{~N}$ was added and distillation was started. The reagent ( $10 \mathrm{~mL}$ of boric acid $4 \%$ with four drops of methyl red and methylene blue mixture) was placed under the outlet of the Kjeldahl distiller. One hundred $\mathrm{mL}$ of the output solution was titrated with $0.01 \mathrm{~N}$ sulfuric acid. The following formula was used to calculate the protein content $(\mathrm{mg} / \mathrm{mL})$.

$$
\text { Protein volume }=\frac{\text { Titration volume } \times 0.14 \times 25 \times 6.25}{50}
$$

\section{Venoms Electrophoresis}

Electrophoresis was performed to check the protein profile of the venoms and its quality. Sodium dodecyl sulfate-polyacrylamide gel electrophoresis (SDS-PAGE) was performed according to the method of Laemmli with modifications (22). 12\% Separating gels and 4\% stacking gels were used (the total volume was enough for two gels with $0.75 \mathrm{~mm}$ spacer). Glass plates were cleaned with ethanol and casting stand was assembled by following manufacturer's instructions (BioRad, USA). $12 \%$ separating gels was prepared by adding the solution (3 mL, 30\% Acrylamide/Bis; $1.9 \mathrm{~mL} 1.5 \mathrm{M}$ Tris$\mathrm{HCl}(\mathrm{pH} 8.8) ; 75 \mu \mathrm{L} \mathrm{10 \%} \mathrm{SDS;} 2.5$ mL ddH ${ }_{2} \mathrm{O} ; 37.5 \mu \mathrm{L} 10 \%$ ammonium persulfate; $10 \mu \mathrm{L}$ TEMED). The solution mixed well and quickly transferred by using pipette to the casting chamber between the glass plates and filled up to about $1.5 \mathrm{~cm}$ below the top of longer plate. A layer of distilled $\mathrm{ddH}_{2} \mathrm{O}$ was added over the top of the resolving gel to prevent polymerization. After $20 \mathrm{~min}$, once the separating gel has polymerized, the $\mathrm{ddH}_{2} \mathrm{O}$ layer was removed by using filter paper. $4 \%$ separating gel was prepared by adding the solution $(1 \mathrm{~mL}, 30 \%$ Acrylamide/Bis; $1.9 \mathrm{~mL} 0.5 \mathrm{M}$ Tris- $\mathrm{HCl}(\mathrm{pH} 6.8) ; 75 \mu \mathrm{L}$

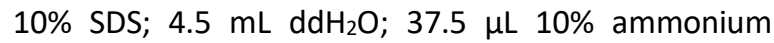
persulfate; $10 \mu \mathrm{L}$ TEMED). The solution mixed well and quickly transferred by using a pipette until the space was full, and then the comb was inserted to the top of the spacers. After $\mathbf{2 0} \mathrm{min}$, once the separating gel has polymerized, the comb carefully removed. The gel cassette from the casting stand was removed and the clamping frame was put into the electrophoresis tank (the short plate was placed on the inside). Running buffer 1X (3 g Tris-Base; 14.4 g Glycine; 1 g SDS; 990 mL $\mathrm{ddH}_{2} \mathrm{O}$ ) was poured into the electrophoresis tank. $25 \mu \mathrm{L}$ of the sample buffer (10 mL 0.5 M Tris- $\mathrm{HCl}(\mathrm{pH} \mathrm{6.8);} 5$ $\mathrm{mL}$ glycerol; $1 \mathrm{~g} \mathrm{SDS}, 2 \mathrm{~mL} 2$-mercaptoethanol; $1 \mathrm{~mL} 1 \%$

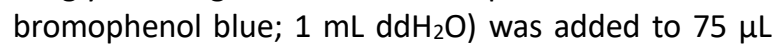
protein samples $(0.5-1.5 \mathrm{mg} / \mathrm{mL})$. Protein samples heated for $10 \mathrm{~min}$ in a boiling water bath and then centrifuged at $13000 \mathrm{rpm}$ for $60 \mathrm{~S}$. $15 \mu \mathrm{L}$ of each protein samples were then loaded onto each gel well as well as load $10 \mu \mathrm{L}$ of protein MW marker and electrophoresis was carried out at a constant voltage (100 V, 2 h). The gel was fixed with $5 \%$ acetic acid overnight and stained for $2 \mathrm{~h}$ in $0.25 \%$ Coomassie blue R-250 in 25\% acetic acid solution. Distaining was carried out in a solution containing $30 \%$ methanol and $10 \%$ acetic acid, until the background became clear.

\section{Lethal Dose of Venoms}

Lethal dose $\left(L_{50}\right)$ of venoms, which is equivalent to death in $50 \%$ of mice within $24 \mathrm{~h}$ after venom injection, was determined by Spearman-Karber Finney methods (23). One $\mathrm{mg} / \mathrm{mL}$ stock of each venom was prepared and centrifuged for $5 \mathrm{~min}$ at $10000 \mathrm{~g}$ and then filtered. Thirty NIH mice (25-30 g) were selected. The mice were maintained at an appropriate temperature $\left(23 \pm 2^{\circ} \mathrm{C}\right)$ with free access to water and food. Five groups of mice were treated with different doses of venom $(1,1.5,2$, $2.5,3 \mathrm{mg} / \mathrm{kg}$ ) and normal saline was injected into a control group. 


\section{Antibacterial Effects of Venoms}

Lyophilized crude venoms $(25,50,75,100 \mu \mathrm{g})$ and its fractions dissolved in $1 \mathrm{~mL}$ of $50 \mathrm{mM}$ Tris- $\mathrm{HCl}$ buffer $(\mathrm{pH}$ 7.4), were filtered using $0.22 \mu \mathrm{m}$ syringe filter and stored at $4^{\circ} \mathrm{C}$ for the assay. Antibacterial susceptibility tests were performed by the disc diffusion assays (19). First, to prepare the disks, different concentrations of venoms were poured onto blank discs and it took $3 \mathrm{~h}$ for the discs to dry completely. Then plates containing Mueller Hinton Agar were cultured with a swab soaked in a bacterial suspension equivalent to half a McFarland and the prepared discs were placed on the surface of the plate. The plates were incubated for $24 \mathrm{~h}$ at $37^{\circ} \mathrm{C}$. Then, the effects of different concentrations of venoms on bacteria were investigated. In this experiment, gentamicin antibiotic disc $(10 \mu \mathrm{g} /$ disk) was used as a positive control.

\section{Statistical Analysis}

Means and standard deviations of the zone inhibition data were collected and calculated using Microsoft Excel. Student's t-test was used to determine statistical significance. $P$-value $<0.05$ was considered statistically significant.

\section{Results}

The protein content was improved in the antibacterial active crude venoms of $E$. carinatus $(1.7$ $\mathrm{mg} / \mathrm{mL}), M$. eupeus $(1.2 \mathrm{mg} / \mathrm{mL}), A$. mellifera $(0.4$ $\mathrm{mg} / \mathrm{mL}$ ), respectively. Electrophoresis revealed that the range of $E$. carinatus proteins was distributed in the light, medium and heavy molecular weight; However, most $M$. eupeus venom proteins were in the average molecular weight range and proteins of A. mellifera venom was in the light molecular range (Figure 1).

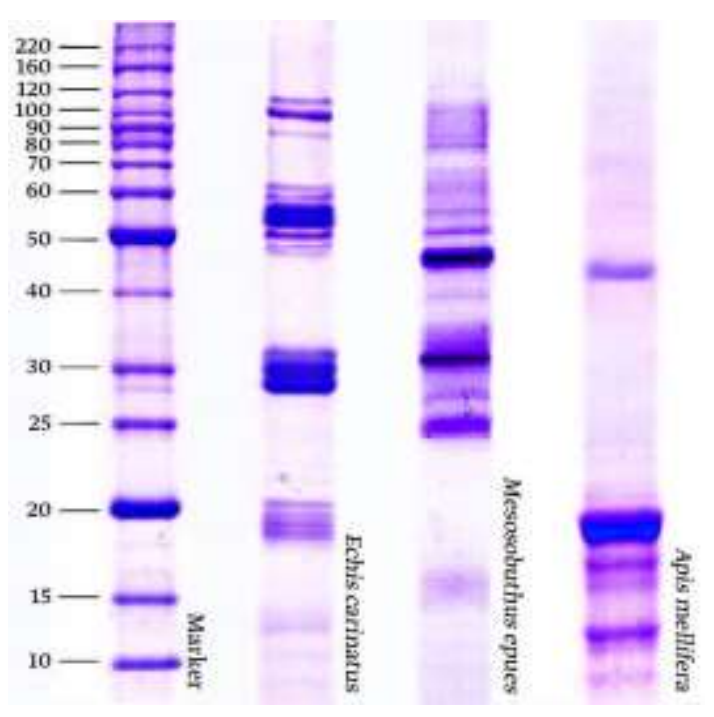

Figure 1. SDS-PAGE profile of E. carinatus, M. eupeus and A. mellifera crude venoms

Chromatography showed that $E$. carinatus and $A$. mellifera had three fractions (Figures 2 and $\underline{4}$ ) and $M$. eupeus had four fractions (Figure 3 ).

The numbers of dead mice within $24 \mathrm{~h}$ were recorded for each venom. After the registration of deaths, the $L_{50}$ of each venom was determined, which are as follows:
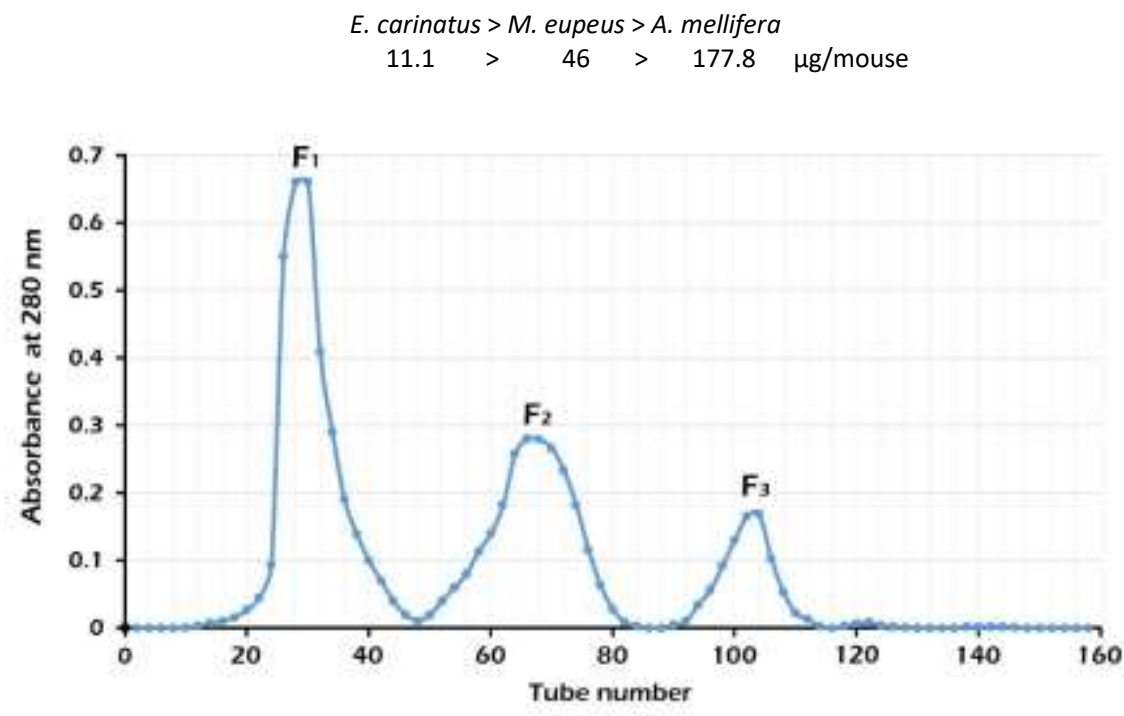

Figure 2. E. carinatus venom chromatogram 


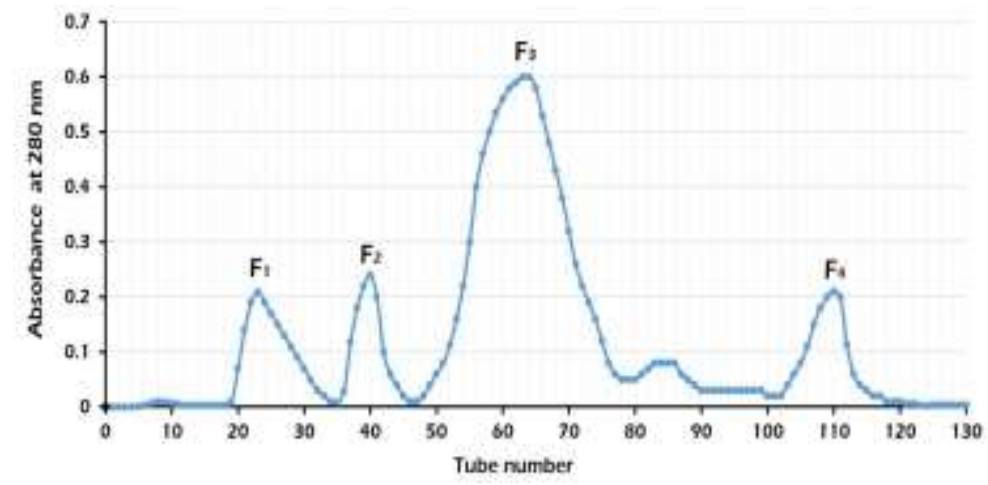

Figure 3. M. eupeus venom chromatogram

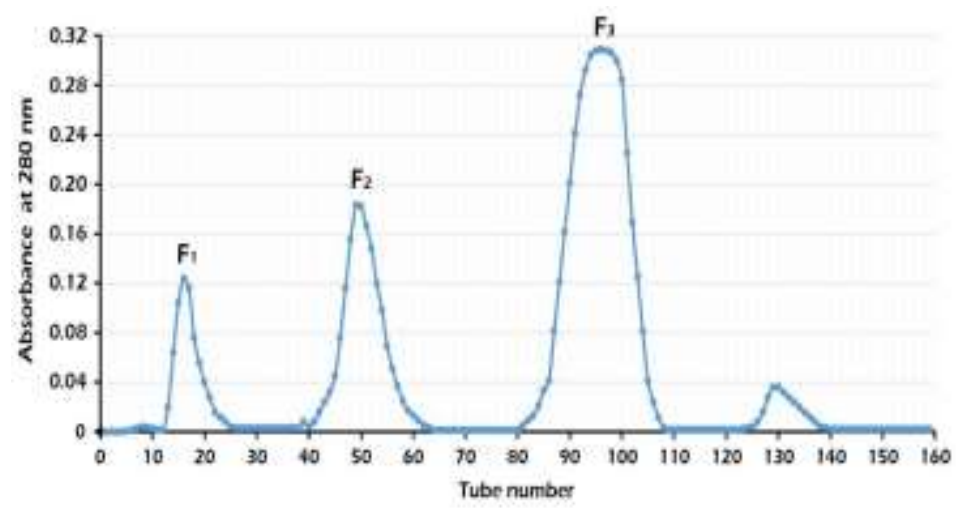

Figure 4. A. mellifera venom chromatogram

E. carinatus crude venom and its fractions has shown no antibacterial effects against $P$. aeruginosa and $B$. subtilis. In contrast, the crude venom was effective against $S$. aureus $(50,75$ and $100 \mu \mathrm{g} / \mathrm{mL})$ and E. coli $(75$ and $100 \mu \mathrm{g} / \mathrm{mL}$ ). In addition, $F_{2}$ was effective against $S$. aureus and E. coli. However, standard antibiotics were shown to be effective against all bacteria (Figure 5 and Table 1). The examination showed that the antibacterial activity of $F_{2}$ against $E$. coli was more significant than it was for the gentamicin at $10 \mu \mathrm{g} / \mathrm{mL}$ (Figure 5).
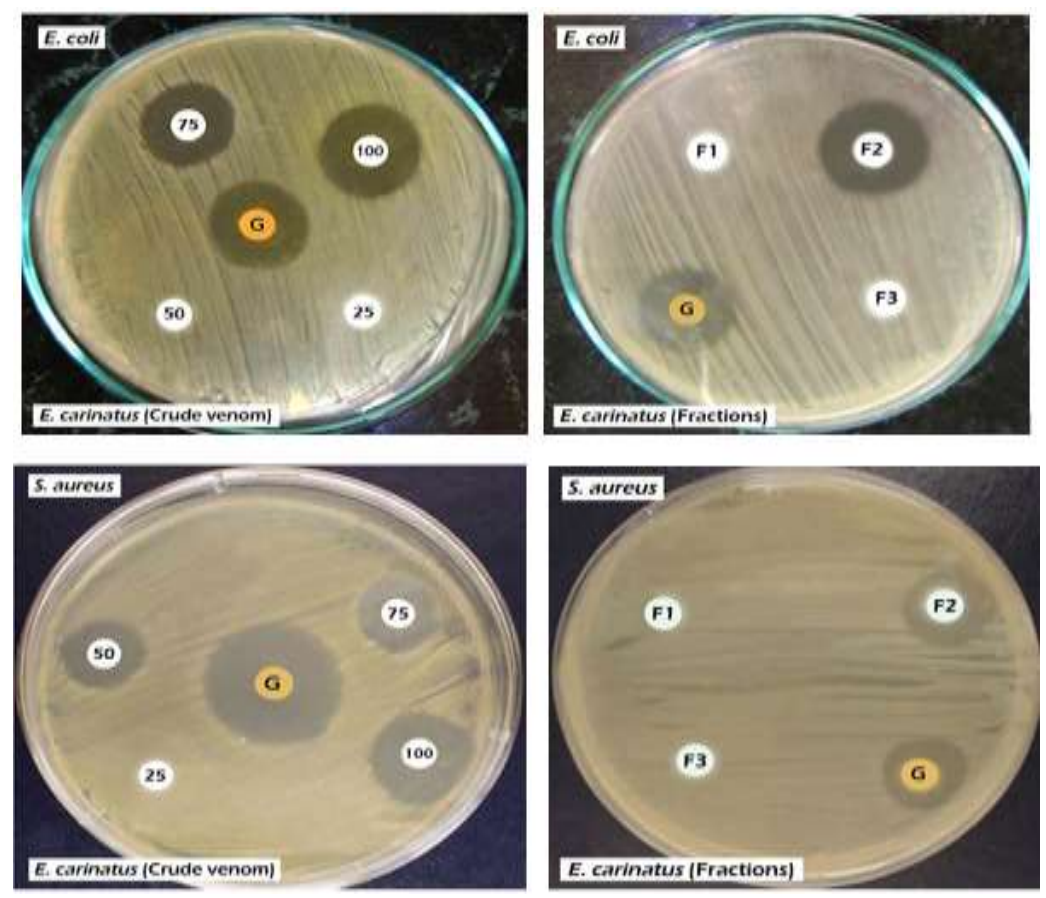

Figure 5. Antibacterial effect of $E$. carinatus crude venoms and fractions against $E$. coli and $S$. aureus 
M. eupeus crude venom and its fractions has shown no antibacterial effects against $P$. aeruginosa, $S$. aureus and $E$. coli. In contrast, $M$. eupeus crude venom was effective against $B$. subtilis $(50,75$ and $100 \mu \mathrm{g} / \mathrm{mL})$. In addition, $F_{1}$ and $F_{4}$ was effective against $B$. subtilis. However, the standard antibiotic gentamicin was effective against those bacteria (Figure 6 and Table 1). The examination showed that the antibacterial activity of $M$. eupeus crude venom (at the 75 and $100 \mu \mathrm{g} / \mathrm{mL}$ concentrations) and $F_{1}$ and $F_{4}$ against $B$. subtilis were more significant than it was for the standard antibiotic gentamicin at $10 \mu \mathrm{g} / \mathrm{mL}$ (Figure 6).
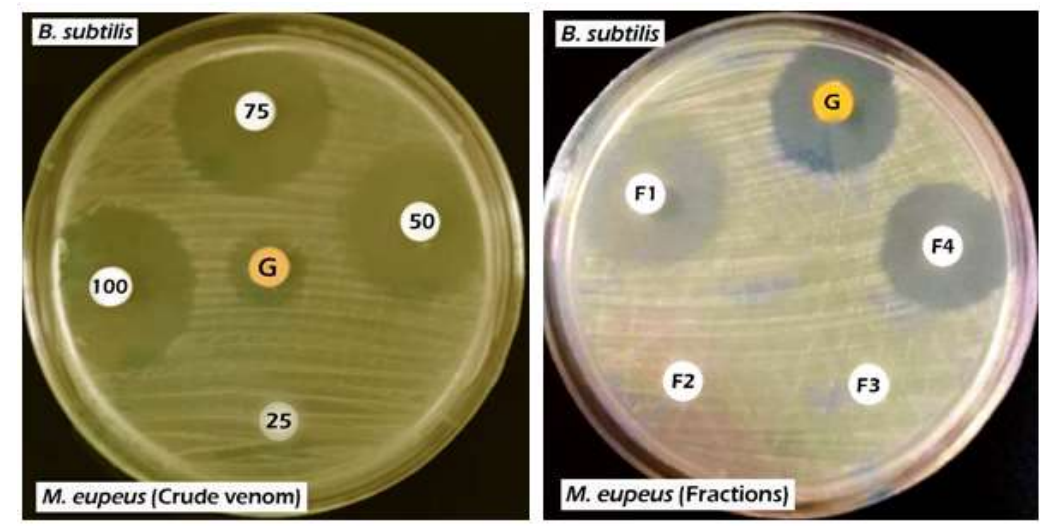

Figure 6. Antibacterial effect of $M$. eupeus crude venoms and fractions against $B$. subtilis

A. mellifera venom demonstrated antibacterial activity against Escherichia coli, S. aureus at all four concentrations. Moreover, with increasing A. mellifera venom concentration, the inhibition zone increased. Fraction $3\left(F_{3}\right)$ of $A$. mellifera crude venom have inhibition effect for $E$. coli and S. aureus (Figure 7).

The venom concentration of $100 \mu \mathrm{g} / \mathrm{mL}$ showed the highest inhibition zone against $E$. coli $(29.06 \pm 1.31$ $\mathrm{mm}$ ) and $S$. aureus $(17.51 \pm 1.07 \mathrm{~mm}$ ) (Table 1 ). $A$. mellifera crude venom and $\mathrm{F}_{3}$ had a more significant antibacterial activity against $E$. coli in the medium than it did against either of the three other strains of bacteria.
The present examination also showed that the antibacterial activity of $A$. mellifera crude venom at the $100 \mu \mathrm{g} / \mathrm{mL}$ concentrations against $E$. coli and $S$. aureus was more significant than it was for the standard antibiotic gentamicin at $10 \mu \mathrm{g} / \mathrm{mL}$ (Figure 7). However, the antibacterial activities of $A$. mellifera crude venom against $S$. aureus $(25$ and $75 \mu \mathrm{g} / \mathrm{mL}$ ) and E. coli ( 25 and $50 \mu \mathrm{g} / \mathrm{mL}$ ) were less than the effect of the standard antibiotic gentamicin at $10 \mu \mathrm{g} / \mathrm{mL}$ (Figure 7). Furthermore, A. mellifera crude venom and its fractions was found to have no observable effect on the $P$. aeruginos $a$ and $B$. subtilis whereas the standard antibiotic gentamicin was effective against those bacteria (Table 1).
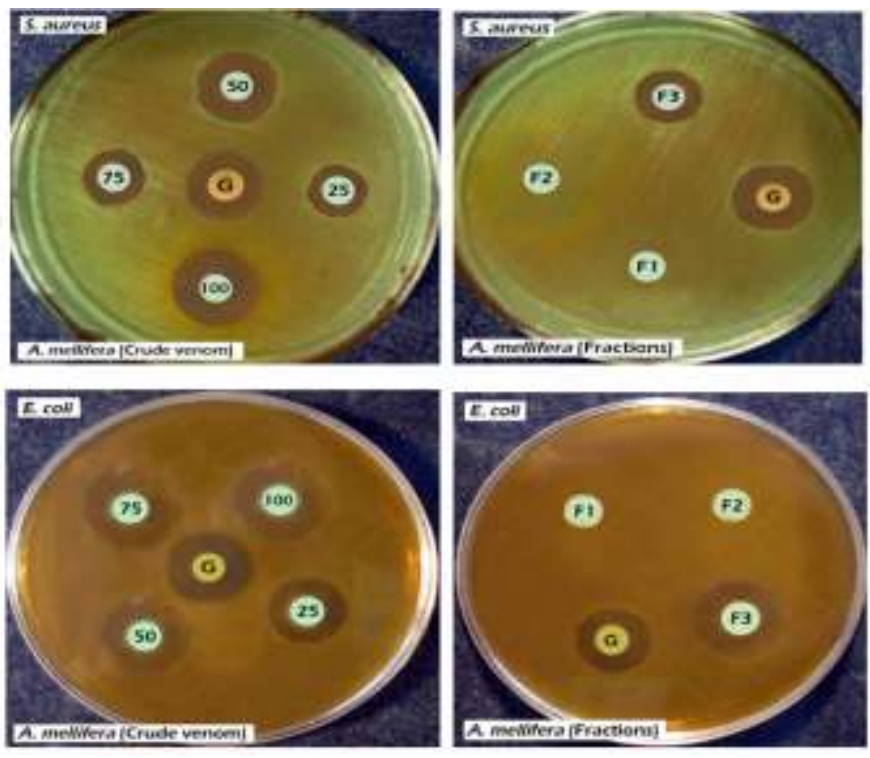

Figure 7. Antibacterial effect of $A$. mellifera crude venoms and fractions against $E$. coli and S. aureus 
Table 1. Values of growth inhibition zones due to crude venom and their fractions of $E$. carinatus, M. eupeus and A. mellifera for bacterial strains

\begin{tabular}{|c|c|c|c|c|c|c|}
\hline \multicolumn{3}{|c|}{ Venoms $\quad$ Bacterial strains } & \multirow{2}{*}{$\begin{array}{c}\text { S. aureus } \\
\text {---- }\end{array}$} & \multirow{2}{*}{ P. aeruginosa } & \multirow{2}{*}{$\begin{array}{c}\text { E. coli } \\
\text {---- }\end{array}$} & \multirow{2}{*}{ B. subtilis } \\
\hline \multirow{9}{*}{ 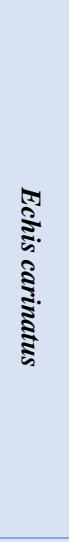 } & \multirow{4}{*}{ 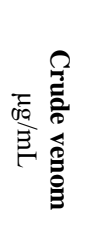 } & 25 & & & & \\
\hline & & 50 & $12.92 \pm 1.03$ & --- & --- & ---- \\
\hline & & 75 & $15.21 \pm 1.56$ & ---- & $21.08 \pm 0.13$ & ---- \\
\hline & & 100 & $22.65 \pm 2.1$ & ---- & $23.91 \pm 0.13$ & ---- \\
\hline & \multicolumn{2}{|c|}{ Gentamicin } & $25.65 \pm 1.64$ & $21.08 \pm 1.08$ & $22.11 \pm 0.22$ & $19.21 \pm 0.97$ \\
\hline & \multirow{3}{*}{ 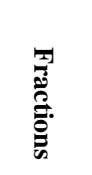 } & $\mathrm{F}_{1}$ & ---- & ---- & ---- & ---- \\
\hline & & $\mathrm{F}_{2}$ & $17.2 \pm 1.42$ & ---- & $24.11 \pm 0.98$ & ---- \\
\hline & & $\mathrm{F}_{3}$ & --- & --- & --- & ---- \\
\hline & \multicolumn{2}{|c|}{ Gentamicin } & $16.1 \pm 0.98$ & $19.11 \pm 1.06$ & $22.54 \pm 1.04$ & $18.83 \pm 1.17$ \\
\hline \multirow{10}{*}{ 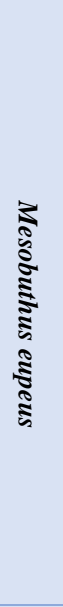 } & \multirow{4}{*}{ 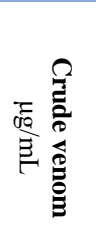 } & 25 & --- & --- & --- & --- \\
\hline & & 50 & --- & --- & --- & $29.20 \pm 0.88$ \\
\hline & & 75 & ---- & ---- & ---- & $29.41 \pm 0.81$ \\
\hline & & 100 & ---- & ---- & ---- & $30.83 \pm 1.04$ \\
\hline & \multicolumn{2}{|c|}{ Gentamicin } & $17.03 \pm 0.81$ & $11 \pm 0.44$ & $20 \pm 0.22$ & $4.22 \pm 0.83$ \\
\hline & \multirow{4}{*}{. } & $\mathbf{F}_{1}$ & ---- & ---- & --- & $29.3 \pm 0.96$ \\
\hline & & $\mathrm{F}_{2}$ & ---- & --- & --- & --- \\
\hline & & $\mathrm{F}_{3}$ & --- & --- & --- & --- \\
\hline & & $\mathrm{F}_{4}$ & ---- & --- & ---- & $26.4 \pm 0.49$ \\
\hline & \multicolumn{2}{|c|}{ Gentamicin } & $20.4 \pm 0.19$ & $31.1 \pm 1.07$ & $16.5 \pm 0.39$ & $25.8 \pm 1.02$ \\
\hline \multirow{9}{*}{ 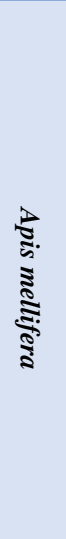 } & \multirow{4}{*}{ 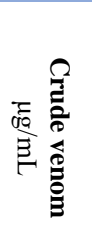 } & 25 & $8.1 \pm 0.76$ & --- & $20.06 \pm 1.50$ & --- \\
\hline & & 50 & $13.2 \pm 0.87$ & --- & $25.30 \pm 1.02$ & --- \\
\hline & & 75 & $9.2 \pm 0.98$ & ---- & $28.31 \pm 0.67$ & ---- \\
\hline & & 100 & $17.51 \pm 1.07$ & ---- & $29.06 \pm 1.31$ & ---- \\
\hline & \multicolumn{2}{|c|}{ Gentamicin } & $11.3 \pm 0.47$ & $19.17 \pm 0.21$ & $26.11 \pm 0.74$ & $9.19 \pm 0.08$ \\
\hline & \multirow{3}{*}{ 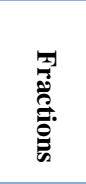 } & $\mathrm{F}_{1}$ & --- & --- & --- & --- \\
\hline & & $\mathrm{F}_{2}$ & --- & --- & --- & --- \\
\hline & & $\mathrm{F}_{3}$ & $8.91 \pm 1.12$ & ---- & $29.51 \pm 1.41$ & ---- \\
\hline & \multicolumn{2}{|c|}{ Gentamicin } & $13.7 \pm 0.89$ & $16.5 \pm 0.47$ & $24.36 \pm 1.09$ & $9.8 \pm 0.29$ \\
\hline
\end{tabular}

\section{Discussion}

The venom of animals such as scorpions, snakes and bees can prevent the growth of microorganisms. For example, scorpions spray their venom on own bodies to prevent the growth of bacteria and fungi (24). In general, the venom of these animals is a good source for pharmaceutical compounds (25). Although some of venoms and compounds derived from them have antibacterial properties, most of them have not been studied for such activities.
The present study provides evidence that venoms of different animals have antibacterial effects against bacteria. Among the venoms examined, those from snake ( $E$. carinatus), scorpion (M. epues) and bee ( $A$. mellifera) showed strong antimicrobial effects. These venoms exhibited greater zones of inhibition, equivalent to that shown by the gentamicin.

With respect to venoms in current study, $A$. mellifera was the most effective against the two microorganisms, among the venoms examined. All 
concentrations of $A$. mellifera venom showed strong antimicrobial effects against $S$. aureus and $E$. coli. Venoms of $E$. carinatus and $M$. eupeus have got medium effects, presenting only three significant venom concentrations.

Compared with the $M$. eupeus venom, which was more specific against $B$. subtilis, the $A$. mellifera and $E$. carinatus venoms, on the other hand, exhibited a broader spectrum of antibacterial activity.

A strong activity was shown against $B$. subtilis by the $M$. eupeus venom, while venoms of $A$. mellifera (25 and $75 \mu \mathrm{g} / \mathrm{mL}$ ) and $E$. carinatus (50 and $75 \mu \mathrm{g} / \mathrm{mL}$ ) exhibited only a weaker activity against $S$. aureus. With respect to microorganism susceptibility, The Gram-positive cocci $S$. aureus bacterium appeared to be the most sensitive to venoms. In contrast, the venoms had no effect on $P$. aeruginosa. The results were consistent with Perumal Samy et al. (26). Previously, snake venoms were reported to exhibit a strong inhibitory effect against $P$. aeruginosa $(27,28)$.

The antibacterial effect of the venom derived from scorpions has been demonstrated in various studies. In a study by Zhao et al. in $\mathbf{2 0 0 9}$ on antibacterial effect of the Chinese scorpion Isometrus maculates, it was found that the venom of this scorpion had an inhibitory effect on the growth of Gram-positive bacteria but no effect on Gram-negative bacteria $P$. aeruginosa and $E$. coli. A comparison of the results of this study with those of the present one suggests that the mechanism of the antibacterial effect of the Chinese scorpion venom is similar to that of the Iranian scorpion venom (29).

In this study, $M$. eupeus crude venom was effective against $B$. subtilis showed zone of inhibition $30 \mathrm{~mm}$. These results are similar to spider venom activity reported by Benli and Yigit (30) and Ahmad et al. (31).

In 2009, in a study on different sources of animal venoms, various species of snakes including Bothrops jararaca, Bothrops moojeni and Bothrops jararacussu were studied for their antibacterial effects. $B$. jararaca had the strongest antibacterial effect on S. aureus (32).

Jami al ahmadi reported that, E. carinatus venom has not a wide spectrum antibacterial effect against the mentioned bacteria, although a significant activity against $S$. aureus in comparison with the standard antibiotics has been observed (33).

A study of antibacterial effect of honey bee venom on several bacteria species in 2016 reported that it had a considerable inhibitory effect on $P$. aeruginosa and $E$. coli (19). In the present study, bee venom was exhibited a strong inhibitory effect against $E$. coli. While in the present study, no antimicrobial activity of bee venom against $P$. aeruginosa was observed.

\section{Conclusion}

Finally, it should be noted that comparison of the antibacterial effects of the venoms with gentamicin suggested that these venoms had stronger inhibitory effects. However, this comparison was a laboratory estimation carried out without a formulation. Therefore, the results obtained in the preliminary stage seem to be valuable. The results of this study indicate that the use of these venoms, especially associated proteins and peptides has promising results. Further research in the future on other bacterial species and on animal models may allow industrial introduction of these venoms into the pharmaceutical market and help solve the drug resistance problem when treating bacterial infections.

\section{Acknowledgment}

The authors thank all those who helped them for this research.

\section{Conflict of Interest}

Authors declared no conflict of interests. 


$$
\begin{aligned}
& \text { مجله ميكروبشناسى يزشكى ايران }
\end{aligned}
$$

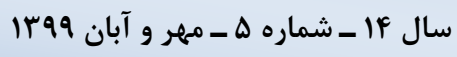

$$
\begin{aligned}
& \text { Journal homepage: www.ijmm.ir }
\end{aligned}
$$

\section{خالصسازى نسبى و تعيين خصوصيات اثرات ضد ميكروبى زهر مار (Echis carinatus)، عقرب (Mesosobuthus epues) و زنبور عسل (Apis mellifera)}

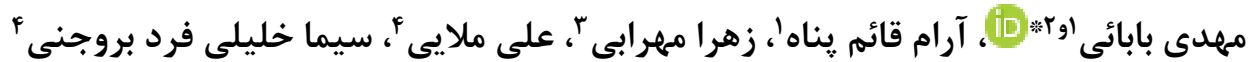

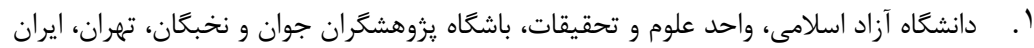

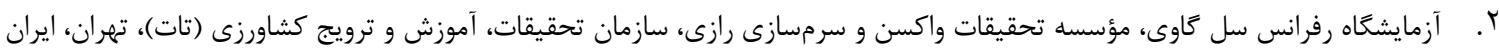

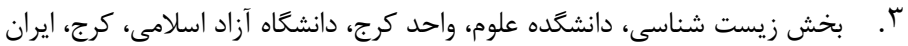

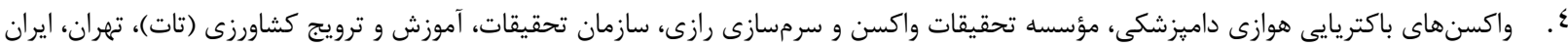

\begin{tabular}{|c|c|}
\hline جكبيده & اطلاعات مقاله \\
\hline 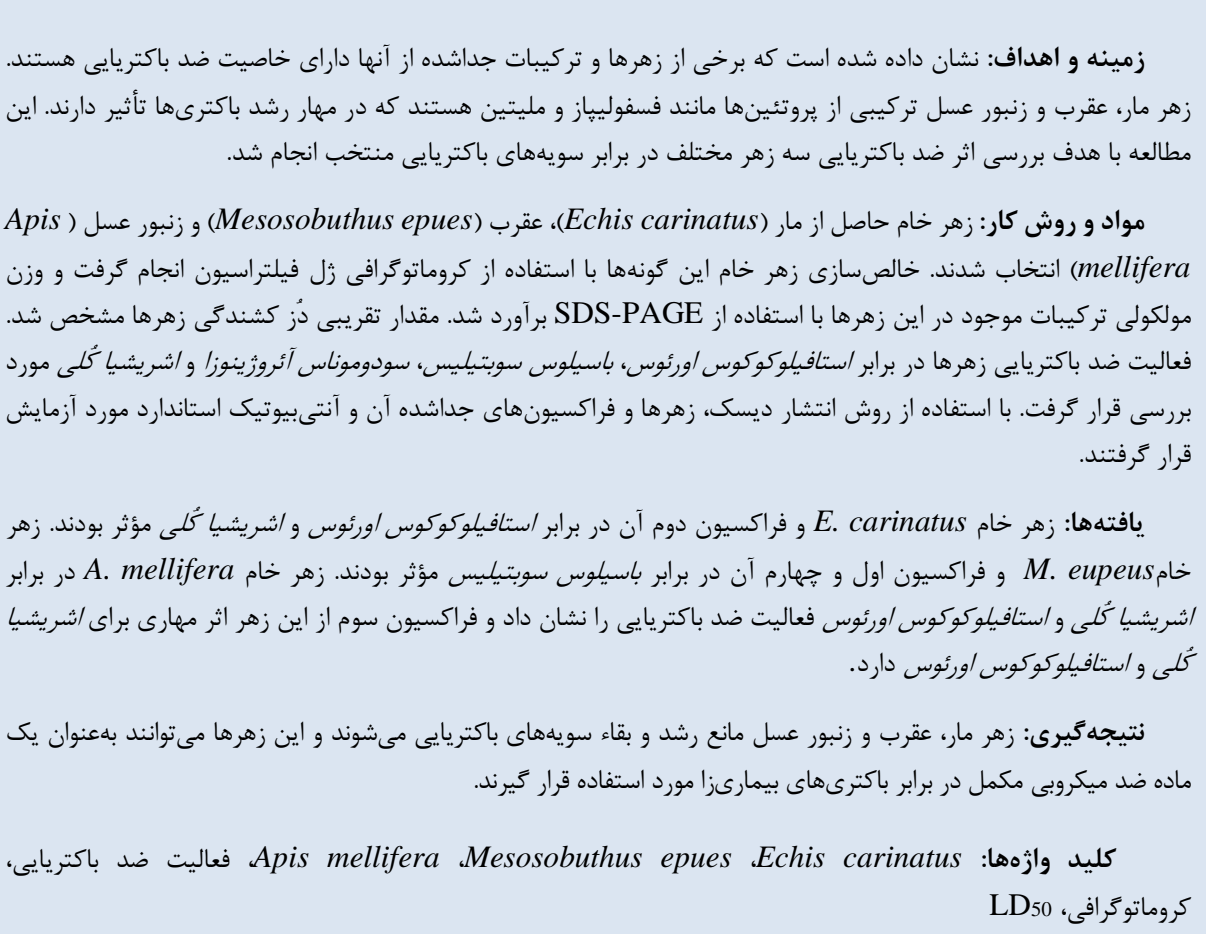 & 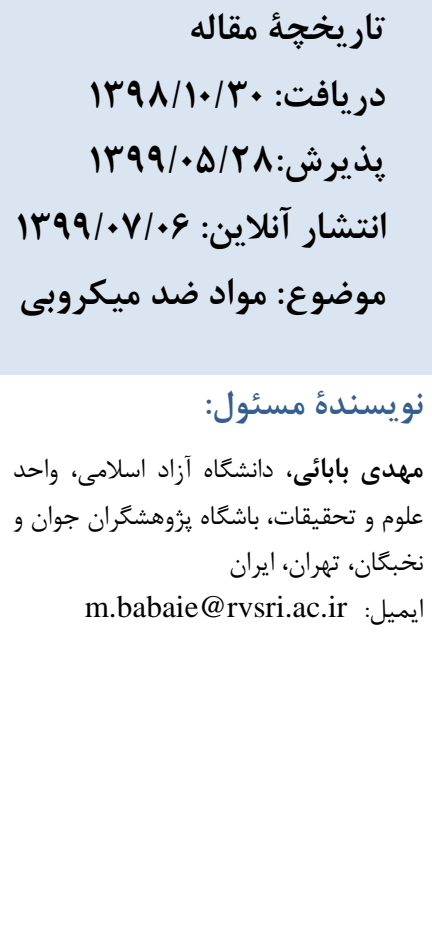 \\
\hline
\end{tabular}

مقدمه

آنتىبيوتيكها به دليل مصرف بيش از حد آنها كاهش يافته است.

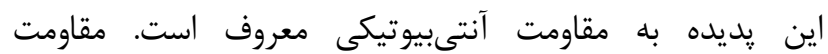

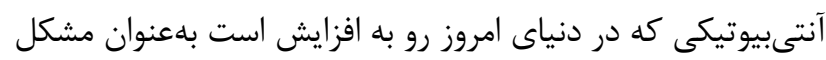
جدى بهداشت عمومى مطرح است و در سال أل • ז، سازمان بهداشت جهانى مقاومت دارويى در برابر آنتىبيوتيكها را يكى مهرئ "تهديد بزرى جهانى " توصيف كرد (r).
بيمارىهاى عفونى كه در اثر عوامل بيمارىزايى مانند باكترىها، ويروسها و غيره ايجاد مىشوند، در سالهاى اخير افزايش يافته است. به دليل كمبود داروهاى مفيد و مؤثر براى درمان بيمارىهاى عفونى، دئ، اين بيمارىها در سراسر جهان در حال كسترش است (1). در حال حاضر درمان آنتىبيوتيكى براى عفونتهاى باكتريايى

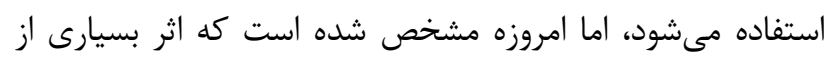


امروزه مطالعات بسيارى با استفاده از روشهاى مولكولى بر روى آند

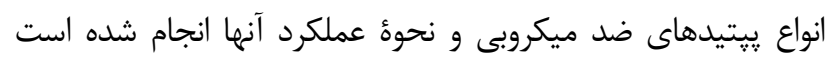

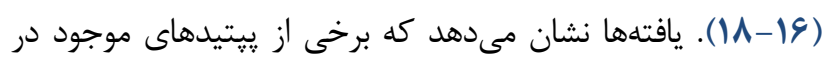

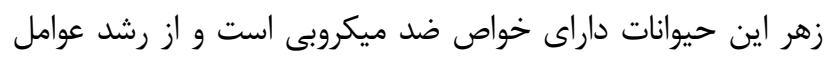

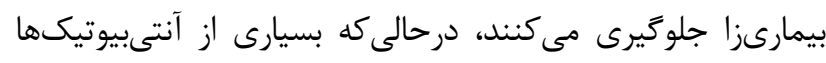

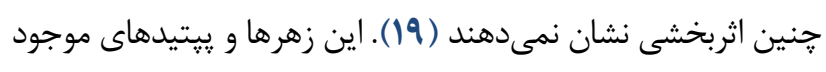

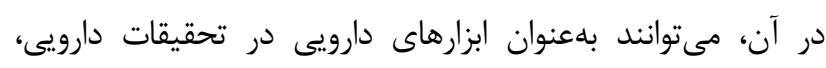

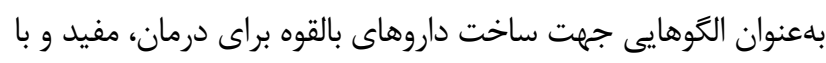

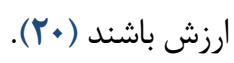

در اين مطالعه اثر ضد ميكروبى زهر مار (Echis carinatus)،

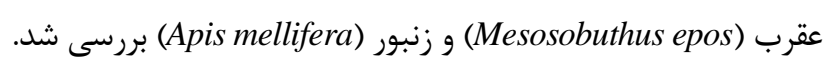

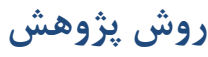

\section{سويdهاى باكترى، حيوانات آزمايشگاهى و ساير مواد}

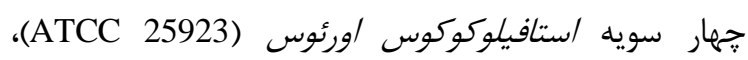

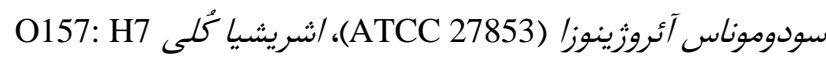
و باسيلوس سوبتيليس (ATCC 25923)

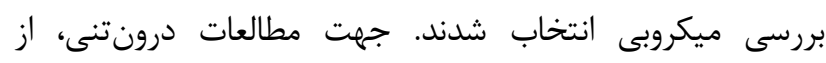

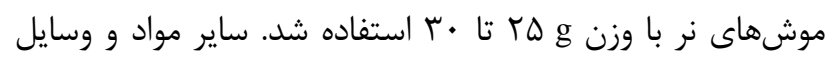

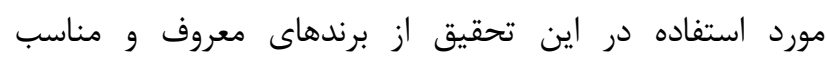
آزمايشگاهى و شيميايى انتخاب شدند (كه در متن انحليسى نام آنها

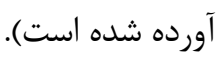

\section{آمادهسازى زهر ها}

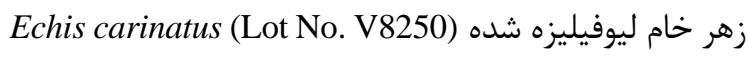

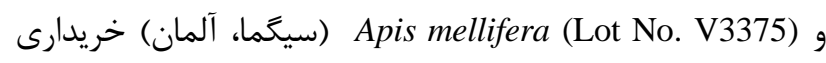

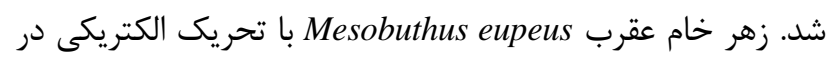

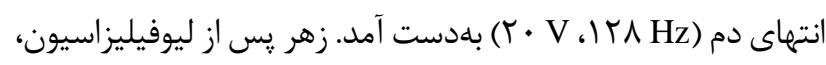

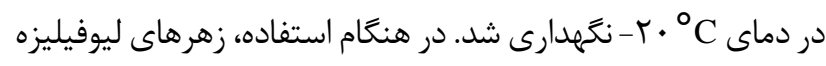

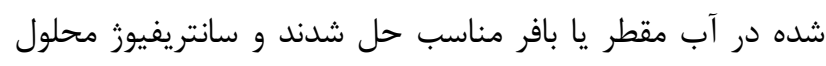

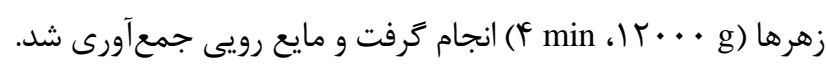

\section{خالصسازى زهرها}

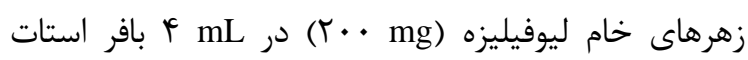

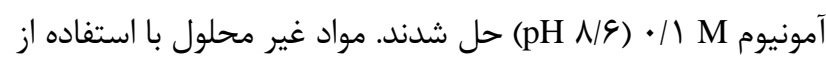

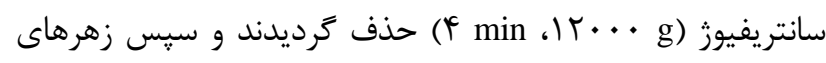

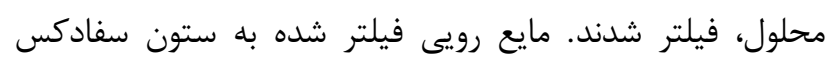

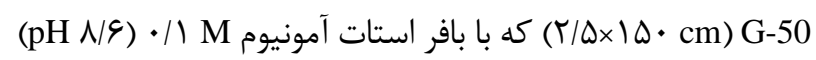

با گسترش مقاومت ضد ميكروبى در سراسر جهان، كشف مواد

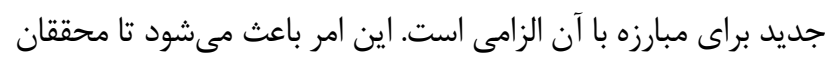

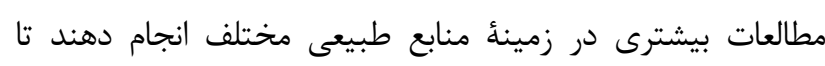

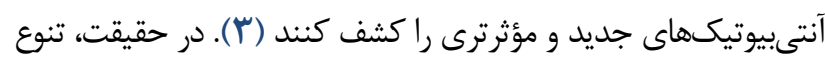

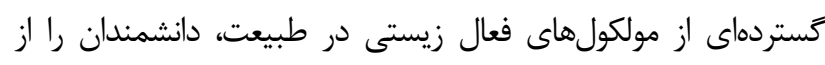

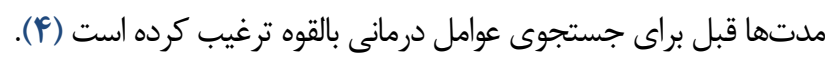

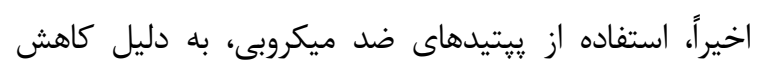

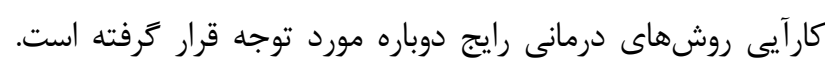

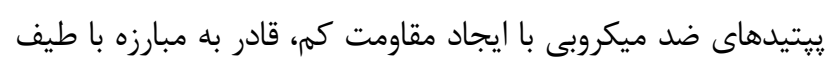

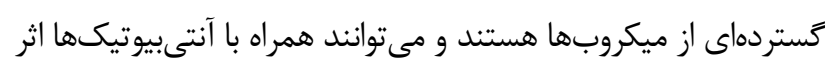

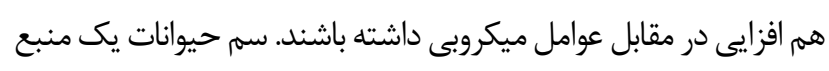
مناسب در زمينه جستجوى تركيبات ضد ميكروبى جديد مى دياشد.

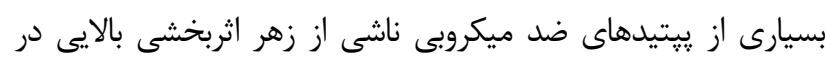

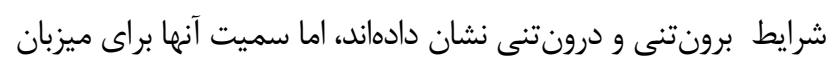

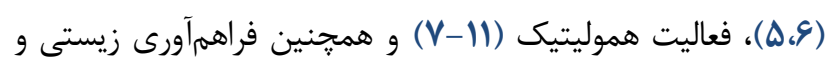

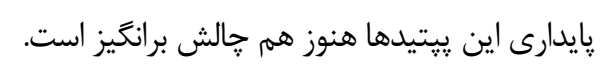

زهر حيواناتى مانند مار، عقرب، عنكبوت، زنبور و غيره مىتواند

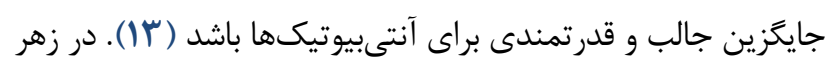

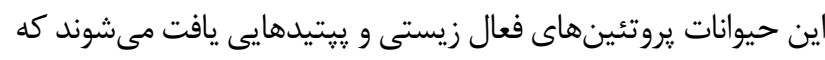

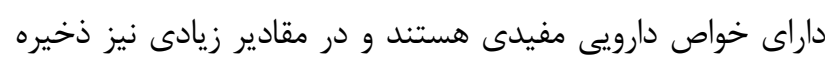

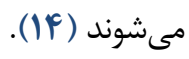

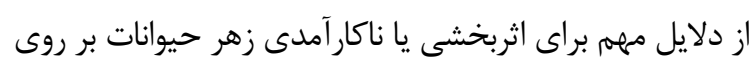

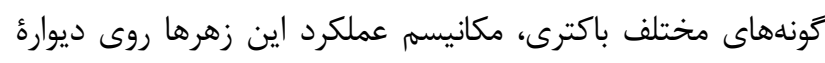

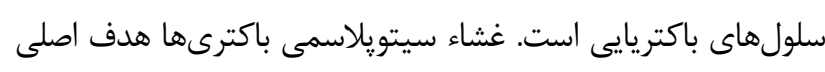

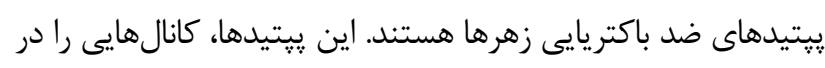

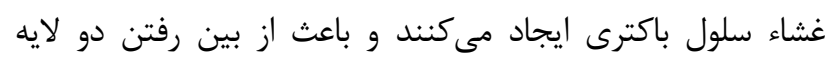

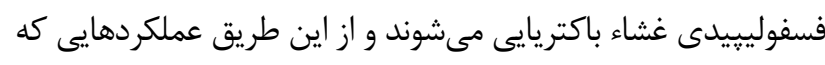

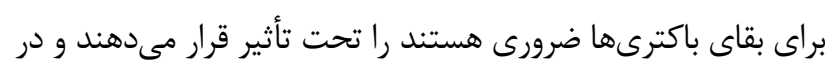

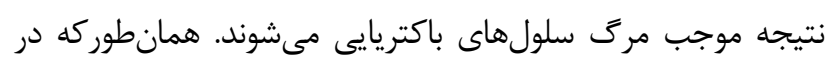

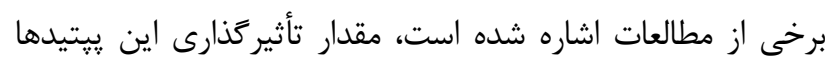

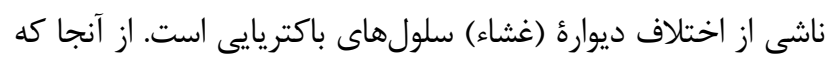

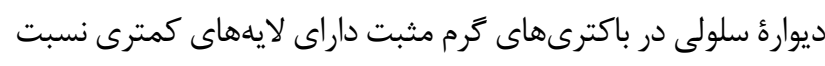

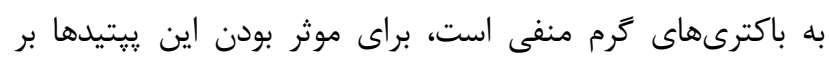

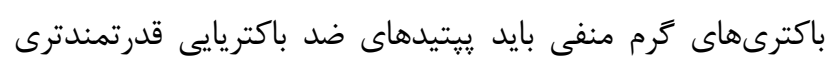

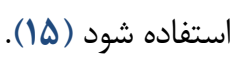


از آنتىبيوتيك جنتامايسين (

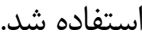

\section{تجزيه و تحليل آمارى}

ميانخين و انحراف معيار دادهها بدست آمده از ناحيه مهار با

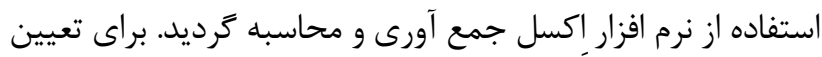

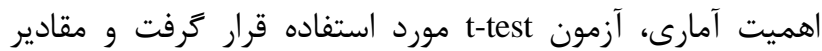
ه•|• P-value از نظر آمارى معنى دار در نظر كرفته شد.

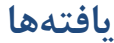

E. carinatus ميزان يروتئين در زهرهاى خام به ترتيب براى $\mathrm{mg} / \mathrm{mL})$ A. mellifera ، (1/T mg/mL) M. eupeus ، (1/V mg/mL)

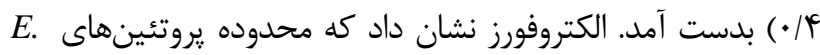
carinatus در وزن مولكولى سبك، متوسط و سنخين توزيع شده است. با اين حال، بيشتر يروتئينهاى زهر M. eupeus در محدوده وزن مولكولى متوسط و يروتئينهاى زهر A. mellifera در محدوده وزن برن مولكولى سبك قرار داشتند (شكل ماتئهاى ).

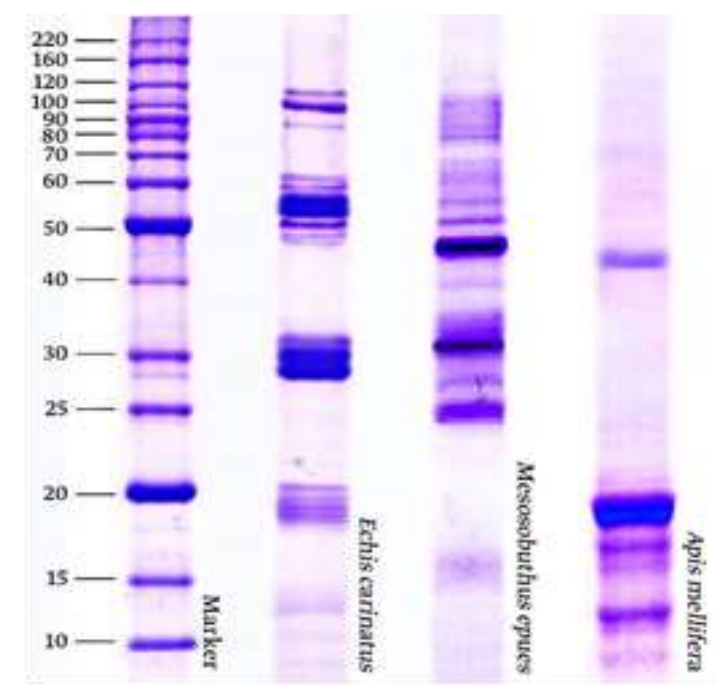

شكل ا. بروفايل SDS-PAGE براى زهرهاى خام M. eupeus ، carinatus و A. mellifera

كروماتوكرافى نشان داد كه A. mellifera g. carinatus داراى سه فراكسيون است (شكل r و \&

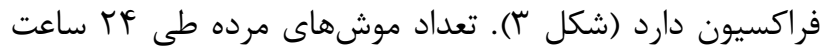

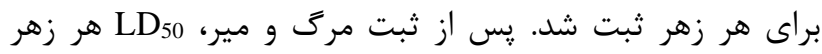
تعيين شد و به شرح زير بلهدست آمد:

E. carinatus $>$ M. eupeus $>$ A. mellifera
11.1
$>\quad 46$
$>177.8$
$\mu \mathrm{g} / \mathrm{mouse}$

به تعادل رسيده بود، تزريق گرديد. شستشو با همان بافر با سرعت

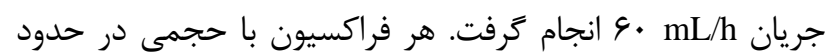

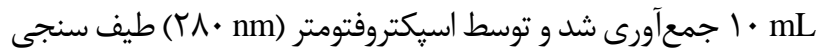

كرديد. فراكسيونهاى نزديك به هم مخلوط و ليوفيليزه شدند (ه).

\section{غلظت بروتئين زهر ها}

ميزان يروتئين موجود در زهرهاى خام با استفاده از روش

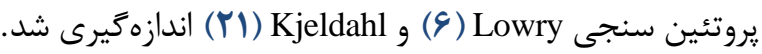

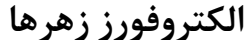

براى بررسى يروفايل بروتئينى زهرها و كيفيت آن، از الكتروفورز

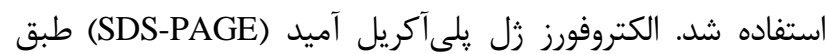
روش Laemmli با إعمال برخى اصلاحات انجام كَرفت (Y (T).

\section{دُز كُشندَى زهرها}

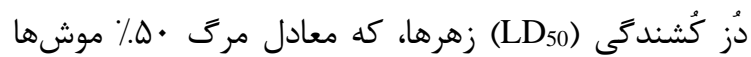

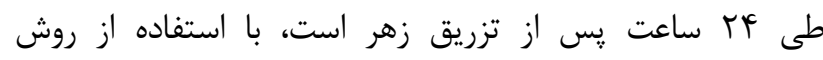
از Spearman-Karber Finey

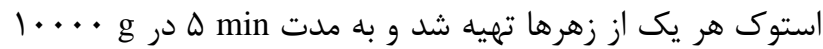

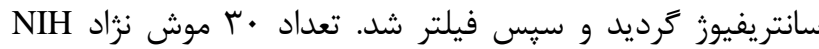
انتخاب شدند. موشها در دماى مناسب (TL-r. g)

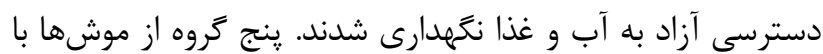

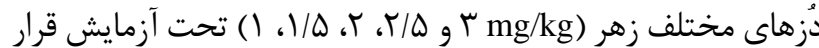
كرفتند و به كروه كنترل نرمال سالين تزريق شد.

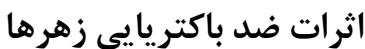

زهرهاى خام ليوفيليزه (

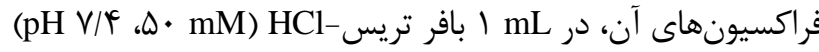

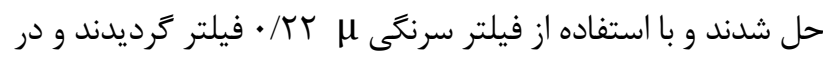

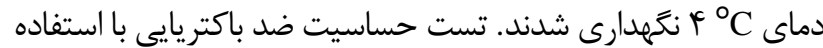
از روش ديسك ديفيوزن انجام كرفت (19). در ابتدا، براى تهيئ ديسك، غلظتهاى (Tg/mL خالى ريخته شد و به مدت سه ساعت زمان داده شد تا ديسكها زها كاملاً خشك شوند. سيس يليتهاى حاوى مولر هينتون آكار با سواب آغشته در سوسيانسيون باكتريايى معادل نيم مك فارلند كشت داده شدند و

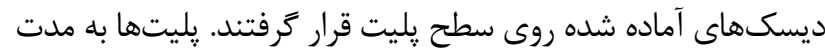

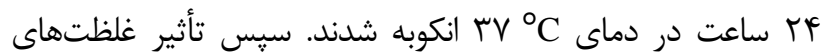
مختلف زهر بر روى باكترىها، مورد بررسى قرار گرفت. در اين آزمايش 


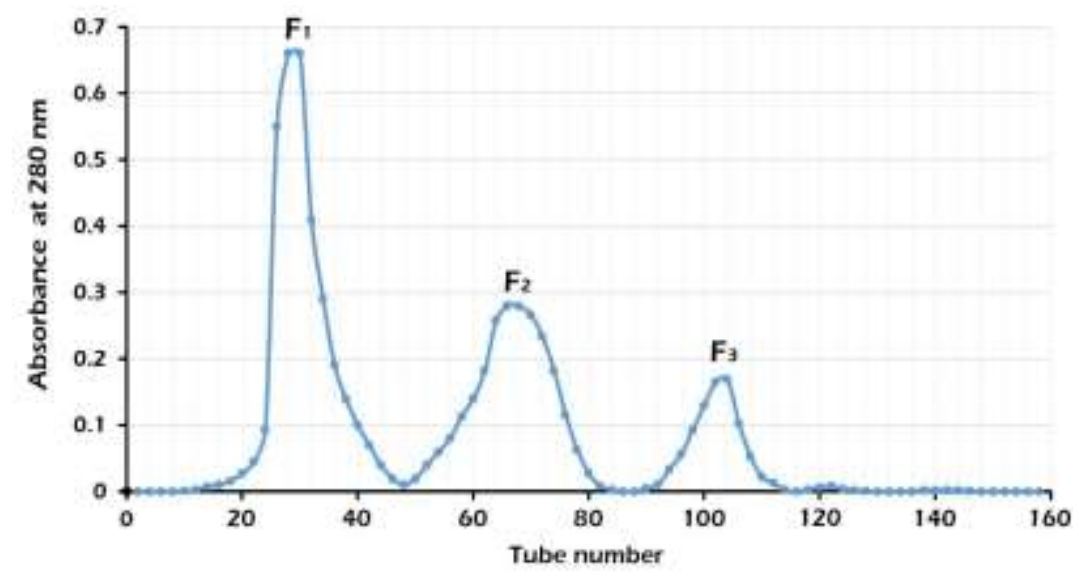

E. carinatus شكل r. كروماتوكرام زهر

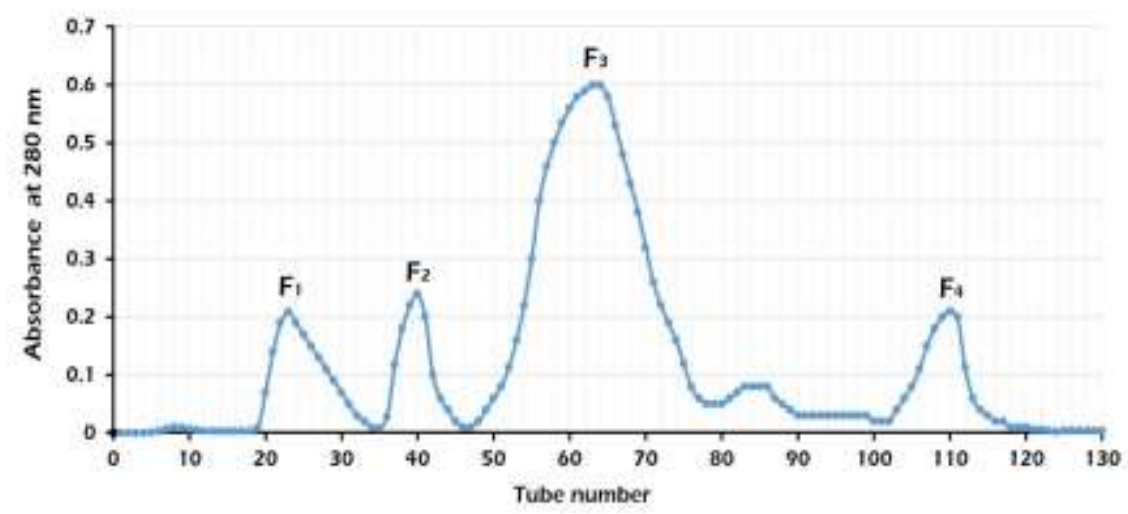

M. eupeus شكل س. كروماتوكرام زهر

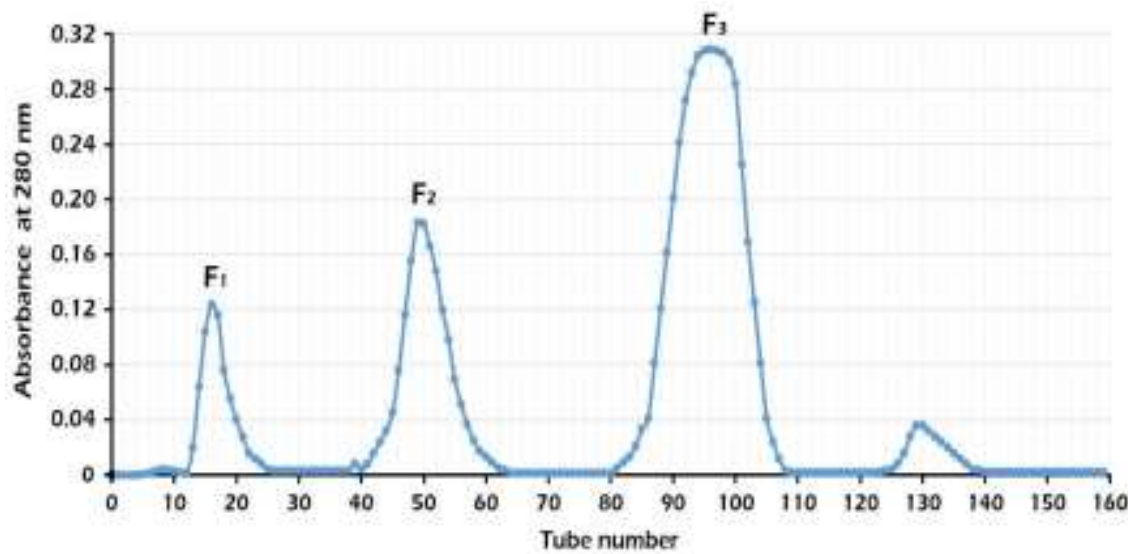

A. mellifera شكل F. كروماتوكرام زهر

در برابر /ستافيلوكوكوس /ورئوس و /شريشيا كُلى مؤثر بود. با اين

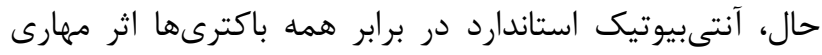

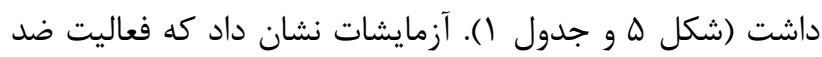

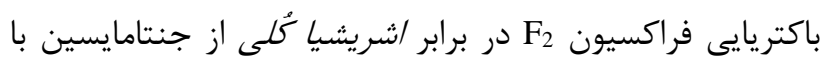
غلظت بg/mL • ا بيشتر (معنى دارتر) است (شكل ه).
زهر خام E. carinatus و فراكسيونهاى آن اثر ضد باكتريايى در برابر سودوموناس آئروزينوزا و باسيلوس سوبتيليليس، نشان فيان ندادند. در مقابل، زهر خام E. carinatus در برابر /ستافيلوكوكوس

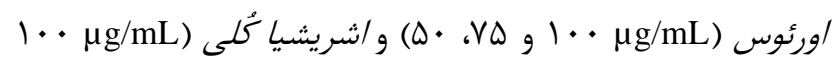

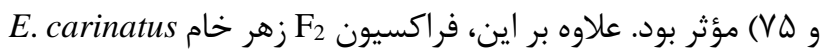



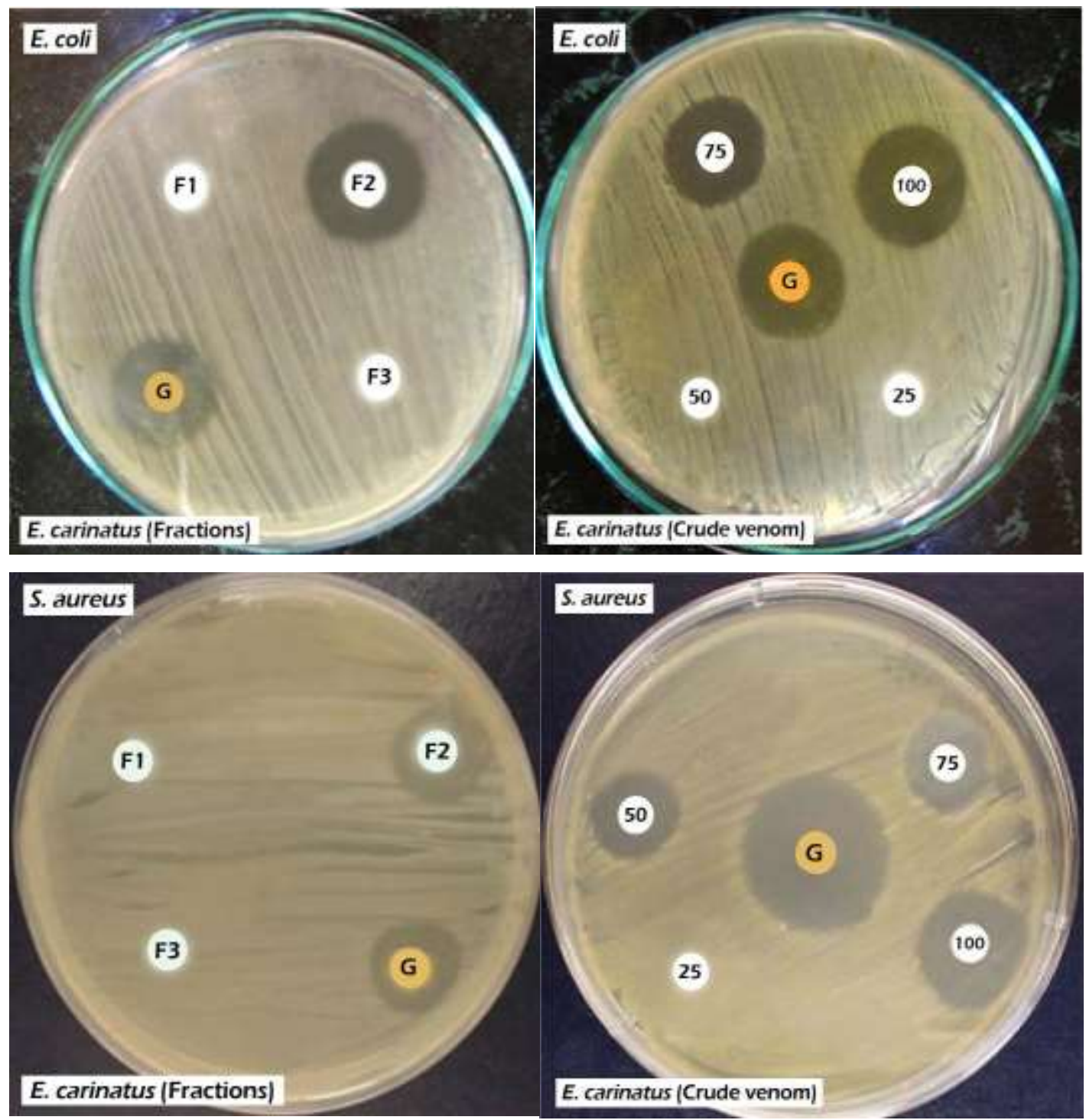

شكل ه. اثر ضد باكتريايى زهر خام E. carinatus فراكسيونهاى آن در برابر استافيلوكوكوس /ورئوس و/شريشيا كُلى

زهر A. mellifera داراى فعاليت ضد باكتريايى در برابر

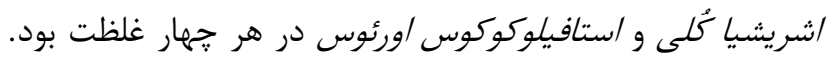
علاوه بر اين، با افزايش غلظت زهر A. mellifera، اندازه ناحيه

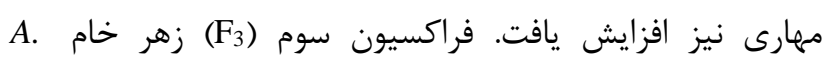

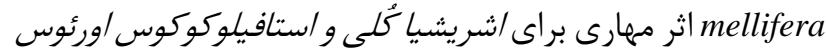

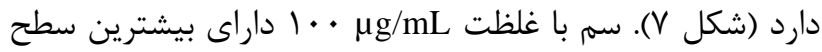

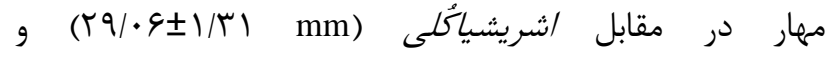

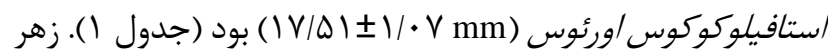

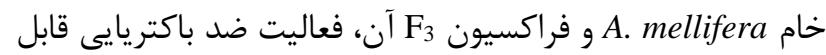

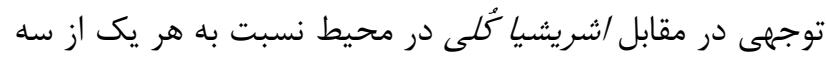
سويه ديخر باكترى داشتند.
زهر خام M. eupeus و فراكسيونهاى آن هيج اثر ضدباكتريايى در برابر سودوموناس آئروزينوزا، استافيلوكوكوس فرام ان هان

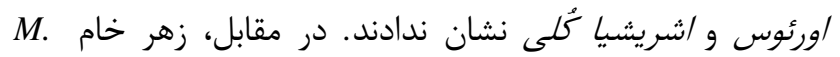
eupeus

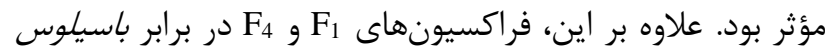
سوبتيليس اثر مهارى داشت. آنتىبيوتيك استاندارد جنتامايسين

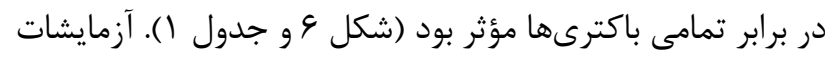
نشان داد كه فعاليت ضد باكتريايى زهر خام M. eupeus (با غلظت F سوبتيليس نسبت به آنتىبيوتيك استاندارد جنتامايسين با غلظت

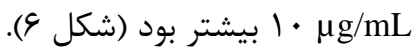




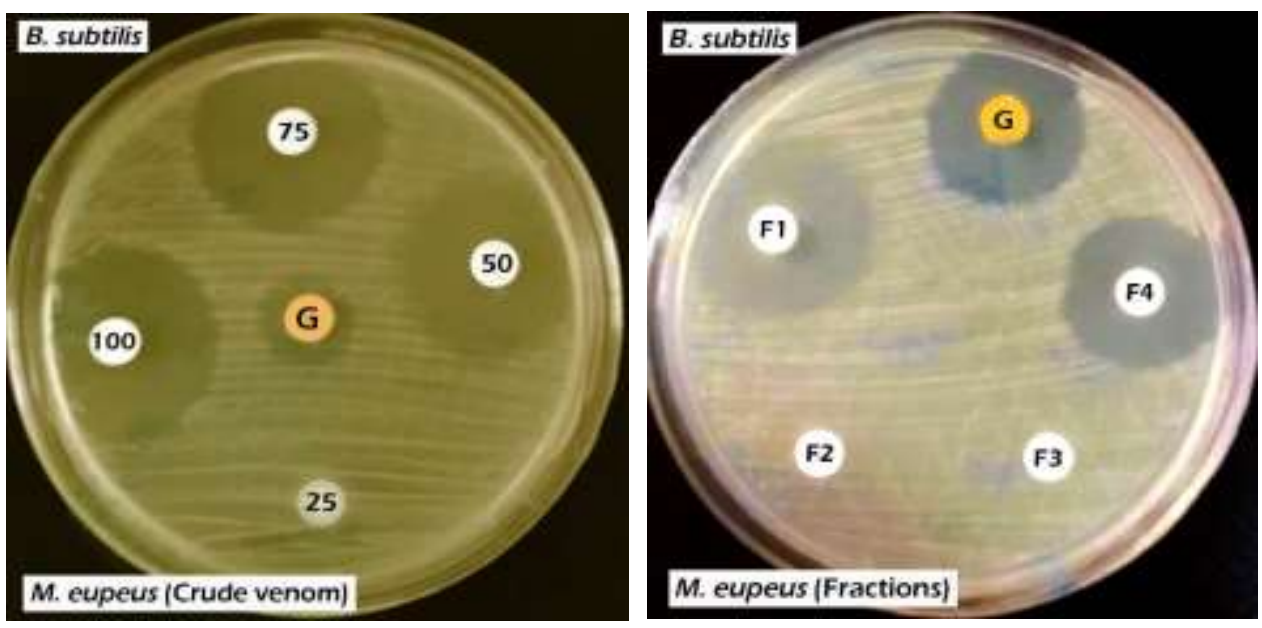

شكل 9. اثر ضد باكتريايى زهر خام M. eupeus و فراكسيونهاى آن در برابر باسيلوس سوبتيليس

اثر آنتىبيوتيك استاندارد جنتامايسين با غلظت بg/mL • • إبود.

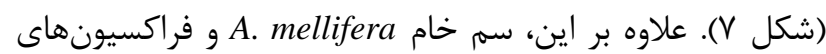

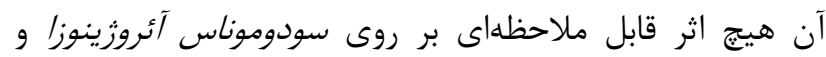

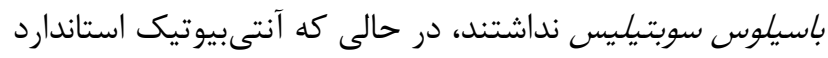

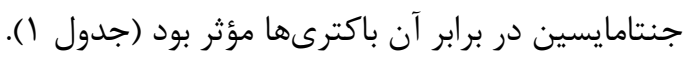

بررسى حاضر همجنين نشان داد كه فعاليت ضد باكتريايى

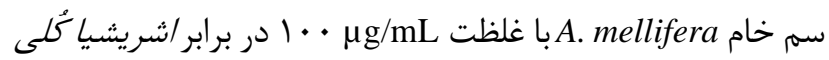

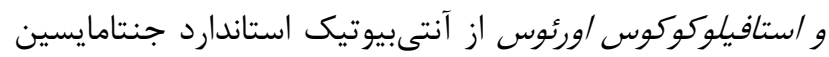

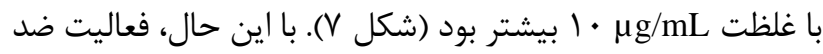

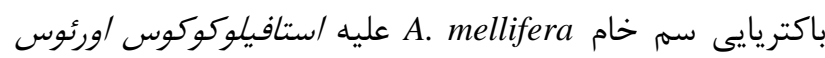

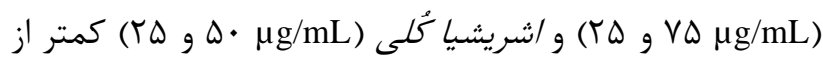

جدول ا. مقادير نواحى مهار رشد ناشى از زهر خام و فراكسيونهاى A. mellifera و M. eupeus ،E. carinatus براى سويههاى باكتريايى

\begin{tabular}{|c|c|c|c|c|c|c|}
\hline باسيلوس سوبتيليس & اشريشيا كُلى & سودوموناس آتروزينوزا & استافيلوكوكوس اورئوس & \multicolumn{3}{|c|}{ سويه هاى باكترى زهر ها } \\
\hline---- & ---- & ---- & ---- & ra & $\widehat{\widehat{े}}$ & \multirow{8}{*}{$\overbrace{}^{2}$} \\
\hline---- & ---- & ---- & $\mid r / q T \pm 1 / \cdot r$ & $\omega$. & $\widehat{\varepsilon}$ & \\
\hline---- & $r / / \cdot \Lambda \pm \cdot / l r$ & ---- & $|\Delta / r| \pm 1 / \Delta \varphi$ & vo & $\stackrel{b}{6}$ & \\
\hline---- & $r r / q 1 \pm \cdot / 1 r$ & ---- & $r T / G \Delta \pm r / l$ & $1 .$. & 然. & \\
\hline$|9 / r| \pm \cdot / 97$ & $r T / l I \pm \cdot / r t$ & $r 1 / \cdot \Lambda \pm 1 / \cdot \Lambda$ & $r \Delta / \& \Delta \pm 1 / \varepsilon r$ & \multicolumn{2}{|c|}{ جنتامايسين } & \\
\hline---- & ---- & ---- & ---- & $\mathrm{F}_{1}$ & \multirow{3}{*}{ 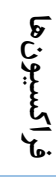 } & \\
\hline--- & $r F / 11 \pm \cdot / 91$ & ---- & $I V / T \pm I / F T$ & $\mathrm{~F}_{2}$ & & \\
\hline--- & ---- & ---- & ---- & $\mathrm{F}_{3}$ & & \\
\hline $\mid N / A r \pm 1 / I V$ & $r Y / \Delta F \pm 1 / \cdot F$ & $19 / 11 \pm 1 / .9$ & $19 / 1 \pm \cdot / 91$ & \multicolumn{2}{|c|}{ جنتاما يسين } & \\
\hline--- & ---- & ---- & ---- & ro & \multirow{4}{*}{ 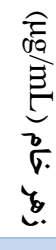 } & \\
\hline$r q / r \cdot \pm \cdot / \Lambda \Lambda$ & ---- & ---- & ---- & $\Delta \cdot$ & & $\$$ \\
\hline$|q / 4| \pm \cdot|\lambda|$ & ---- & ---- & ---- & $v \Delta$ & & $\stackrel{\mathscr{E}}{2}$ \\
\hline$r \cdot \mid \Lambda r \pm 1 / \cdot r$ & ---- & ---- & ---- & $1 .$. & & \\
\hline$F / r T \pm \cdot / \Lambda r$ & $r \cdot \pm \cdot / r r$ & $11 \pm \cdot / 4 F$ & $|V| \cdot r \pm \cdot|\lambda|$ & \multicolumn{2}{|c|}{ جنتاما يسين } & $\begin{array}{c}\overline{2} \\
\Omega\end{array}$ \\
\hline$r q / \Gamma \pm \cdot / 9 ९$ & ---- & ---- & ---- & $\mathrm{F}_{1}$ & \multirow{4}{*}{ 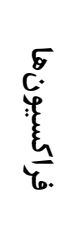 } & $\approx$ \\
\hline---- & ---- & ---- & ---- & $\mathrm{F}_{2}$ & & \\
\hline--- & ---- & ---- & ---- & $\mathrm{F}_{3}$ & & \\
\hline$r \varepsilon / F \pm \cdot / \& q$ & ---- & ---- & ---- & $\mathrm{F}_{4}$ & & \\
\hline
\end{tabular}




\begin{tabular}{|c|c|c|c|c|c|c|}
\hline باسيلوس سوبتيليس & ا اشريشيا كُلى & سودوموناس آئروثينوزا & استافيلوكوكوس اورئوس & \multicolumn{3}{|c|}{ سويههاى باكترى زهرها } \\
\hline$r \Delta / \Lambda \pm 1 / \cdot r$ & $19 / 0 \pm \cdot / \% 9$ & $r / / \pm 1 / \cdot V$ & $r \cdot / 4 \pm \cdot / 19$ & \multicolumn{2}{|c|}{ جنتامايسين } & \\
\hline---- & $r \cdot 1.9 \pm 1 / \Delta$. & --- & $N / 1 \pm \cdot / V q$ & rQ & \multirow{4}{*}{ 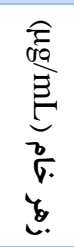 } & \multirow{8}{*}{$\frac{8}{8}$} \\
\hline ---- & $r \Delta / r \cdot \pm 1 / \cdot r$ & ---- & $\mid r / T \pm \cdot / A V$ & $\Delta$. & & \\
\hline ---- & $|Y N / T| \pm \cdot \mid q V$ & ---- & $9 / \pi \pm \cdot / 91$ & $v \Delta$ & & \\
\hline---- & $r q / .9 \pm 1 / r)$ & ---- & $|V / Q| \pm 1 / \cdot V$ & $1 .$. & & \\
\hline $9 / 19 \pm \cdot / \cdot 1$ & $r \varepsilon / 11 \pm \cdot / V \varphi$ & $|9 /| V \pm \cdot / r \mid$ & $11 / r \pm \cdot / 4 V$ & \multicolumn{2}{|c|}{ جنتامايسين } & \\
\hline--- & --- & ---- & --- & $\mathrm{F}_{1}$ & \multirow{3}{*}{ 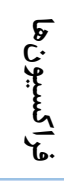 } & \\
\hline ---- & ---- & ---- & ---- & $\mathrm{F}_{2}$ & & \\
\hline---- & $r q / Q| \pm| / 4 \mid$ & ---- & $N / 91 \pm 1 / 1 r$ & $\mathrm{~F}_{3}$ & & \\
\hline $9 / 1 \pm \cdot / r q$ & $T F / Y G \pm 1 / \cdot 9$ & $19 / 0 \pm \cdot / F V$ & $\mid r / v \pm \cdot / \wedge 9$ & \multicolumn{2}{|c|}{ جنتامايسين } & \\
\hline
\end{tabular}
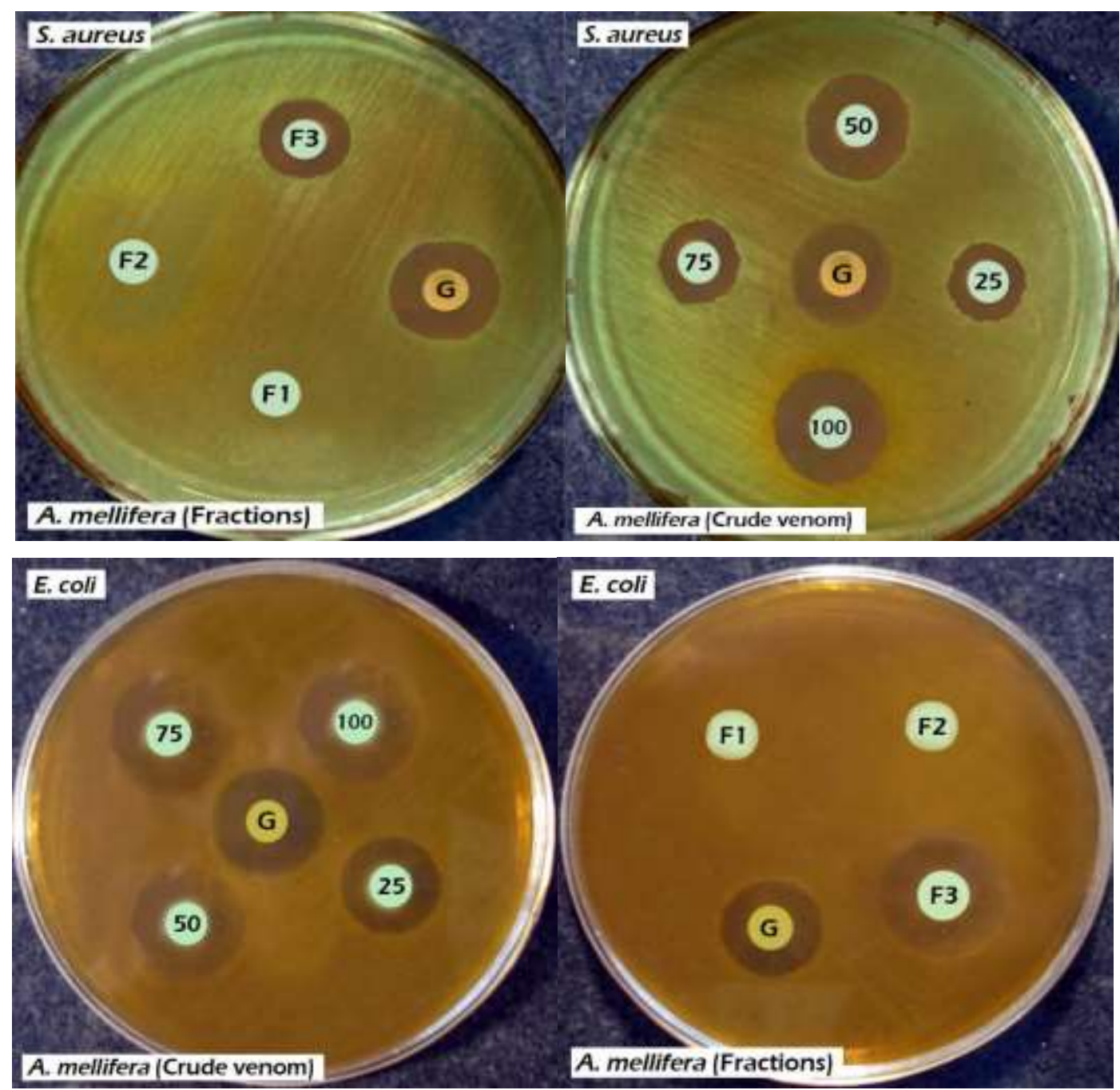

شكل ه. اثر ضد باكتريايى زهر خام A. mellifera فر اكسيونهاى آن در برابر /شريشيا كُلى و استافيلوكوكوس /ورئوس 
در اين مطالعه، زهر خام M. eupeus در برابر باسيلوس

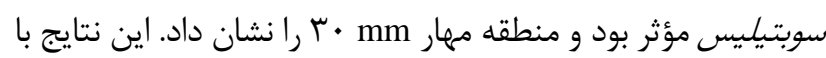

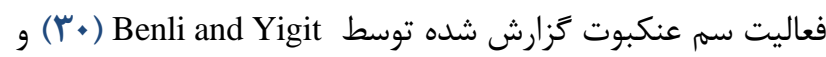
Ahmed در سال 9 × · r، با مطالعه در مورد منابع مختلف زهر حيوانات، Bothrops اثرات ضد باكتريايى زهر گونهاى مختلف مار از جمله Bothrops jararacussu Bothrops moojeni ،jararaca بررسى قرار گرفت. نتايج نشان داد كه زهر B. jararaca قوىترين

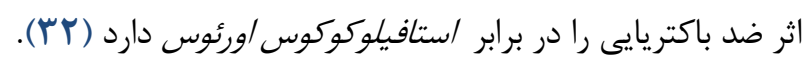
كزارش داد، زهر Jami al ahmadi باكتريايى گستردهاى در برابر باكترىهاى ذكر شده ندارد، اترخه

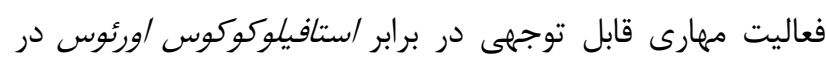

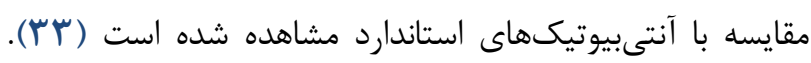

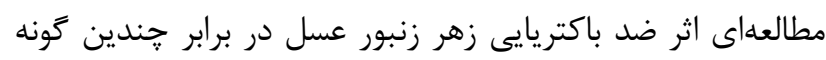

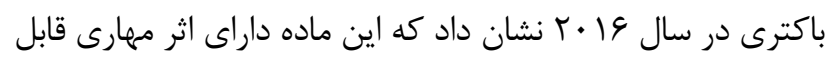
توجهى در برابر سودوموناس آئروزينوزا و /شريشيا كُلىى است (9) (1). در مطالعهُ حاضر، زهر زنبور عسل اثر مهارى قوى در برابر اشريشيا

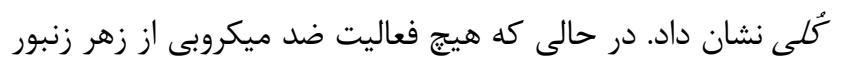
عسل در برابر سودوموناس آئروزينوزا مشاهده نشد.

\section{نتيجه گيرى}

در نهايت، لازم به ذكر است كه مقايسه اثرات ضد باكتريايى

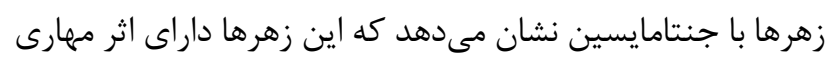
قوىترى هستند. با اين حال، اين مقايسه يك ارزيابى آزمايشعاهيى است كه بدون فرمولاسيون انجام شده است. بنابراين نتايج بهدست آمده در مرحله مقدماتى ارزشمند به نظر مىرسد. نتايج اين مطالعه نشان مىدهد كه استفاده از اين زهرها، بهويزه : يروتئينها و

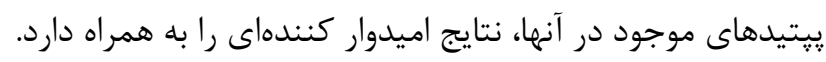
تحقيقات بيشتر در آينده در مورد گونههاى باكتريايى ديخر و مدلهاى حيوانى ممكن است باعث ورود صنعتى اين زهرها به بازار

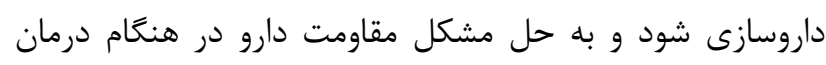
عفونتهاى ميكروبى و بهخصوص عفونت باكتريايى كمك كند.
زهر حيواناتى مانند عقرب، مارها و زنبورها مىتوانند از رشد

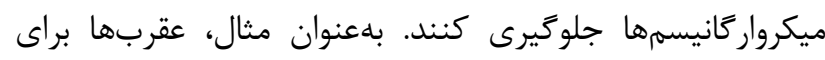
جلوكيرى از رشد باكترىها و قارج ها، زهرشان را بر روى بدن خود

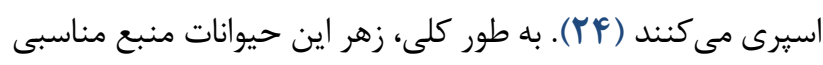
براى تركيبات دارويى است ( (Y). اخرجه برخى از زهرها و تركيبات بلدست آمده از آنها خاصيت ضد باكتريايى دارند، اما اكثر اين زهرها براى جنين فعاليتهايى مورد مطالعه قرار نخرفتهاند. مطالعه حاضر شواهدى را ارائه مى دهد كه زهرهاى مختلف حيوانات داراى اثر ضد باكتريايى در برابر باكترىها هستند. در بين زهرهاى مورد بررسى،

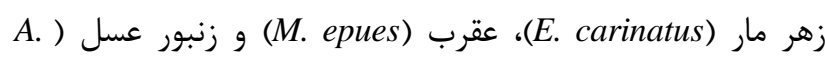
اثرات ضد ميكروبى قوى داشتند و در مواردى، نواحى (mellifera

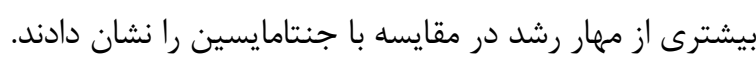

A. در مطالعه حاضر از بين زهرهاى مورد بررسى، زهر mellifera غلظتهاى زهر A. mellifera اثر ضد ميكروبى قوى در بر درابر استافيلوكوكوس /ورئوس و /شريشياكُلى داشتند. زهر E. carinatus

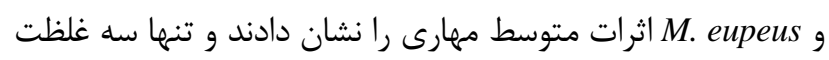
از زهر آنها اثر قابل توجه داشت.

زهر M. eupeus، بهطور خاص در برابر باسيلوس سوبتيليس

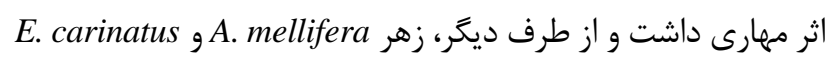
طيف گستردهترى از فعاليت ضدباكتريايى را نشان دادند. با توجه به حساسيت ميكروار گانيسمى، به نظر مىرسد كه باكترى گرم مثبت استافيلوكوكوس اورئوس از جمله حساسترين باكترىها نسبت به به به

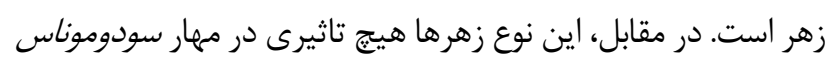

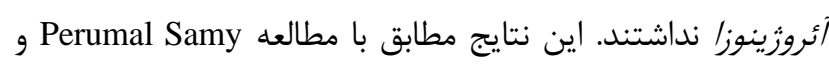

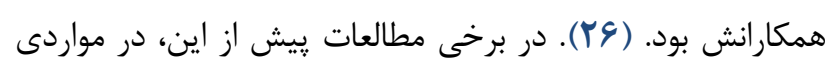
كزارش شده است كه زهر مار اثر مهارى قوى در برابر سودوموناس

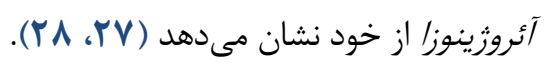
اثر ضد باكتريايى زهر عقرب در مطالعات مختلف نشان داده

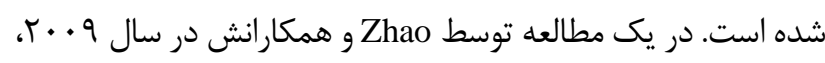
با مطالعه اثر ضد باكتريايى عقرب جينى Isometrus maculates، مشخص شد كه زهر اين عقرب اثر مهارى بر رشد باكترىهاى كرم مثبت دارد، اما هيج تاثيرى بر باكترىهاى گرم منفى سنى سودوموناس

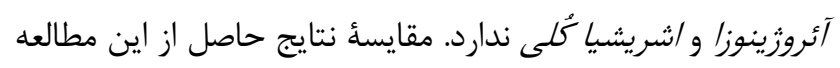
با نتايج موجود نشان مىدهد كه مكانيسم اثر ضد باكتريايى زهر

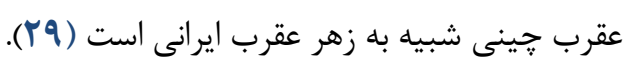




$$
\begin{aligned}
& \text { تعارض در منافع } \\
& \text { اين مقاله يزوهشى مستقل است كه بدون حمايت مالى إنى } \\
& \text { سازمانى انجام شده است. در انجام مطالعئ حاضر، نويسندًان } \\
& \text { هيج كونه تضاد منافعى نداشتهاند. }
\end{aligned}
$$

\author{
سياسگَزارى

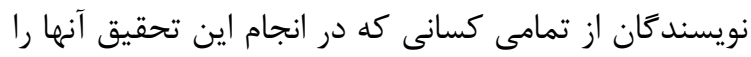 \\ يارى كردند، تشكر و قدردانى مى كنند.
}

\section{Referance}

1. Aslam B, Wang W, Arshad MI, Khurshid M, Muzammil S, Rasool MH, et al. Antibiotic resistance: a rundown of a global crisis. Infect Drug Resist. 2018;11:1645-58. [DOI:10.2147/IDR.S173867] [PMID] [PMCID]

2. Prestinaci F, Pezzotti P, Pantosti A. Antimicrobial resistance: a global multifaceted phenomenon. Pathog Glob Health. 2015;109(7):309-18. [DOI:10.1179/2047773215Y.0000000030] [PMID] [PMCID]

3. Fair RJ, Tor Y. Antibiotics and bacterial resistance in the 21st century. Perspect Medicin Chem. 2014;6:2564. [DOI:10.4137/PMC.S14459] [PMID] [PMCID]

4. Perumal Samy R, Stiles BG, Franco OL, Sethi G, Lim LHK. Animal venoms as antimicrobial agents. Biochem Pharmacol. 2017;134:127-38. [DOI:10.1016/j.bcp.2017.03.005] [PMID]

5. Babaie M, Zolfagharian $\mathrm{H}$, Salmanizadeh $\mathrm{H}$, Mirakabadi AZ, Alizadeh H. Isolation and partial purification of anticoagulant fractions from the venom of the Iranian snake Echis carinatus. Acta Biochim Pol. 2013;60(1):17-20. [DOI:10.18388/abp.2013 1945] [PMID]

6. Babaie M, Zolfagharian $\mathrm{H}$, Zolfaghari $\mathrm{M}$, Jamili S. Biochemical, hematological effects and complications of Pseudosynanceia Melanostigma Envenoming. J Pharmacopuncture. 2019;22(3):140-6.

7. Babaie M, Salmanizadeh H, Zolfagharian H, Alizadeh H. Properties of biological and biochemical effects of the Iranian saw-scaled viper (Echis carinatus) venom. Bratisl Lek Listy. 2014;115(7):434-8. [DOI:10.4149/BLL 2014 085] [PMID]

8. Babaie M, Salmanizadeh H, Zolfagharian H. Blood coagulation induced by Iranian saw-scaled viper (Echis Carinatus) venom: Identification, purification and characterization of a prothrombin activator. Iran J Basic Med Sci. 2013;16(11):1145-50.

9. Salmanizadeh $\mathrm{H}$, Babaie M, Zolfagharian $\mathrm{H}$. In vivo evaluation of homeostatic effects of Echis carinatus snake venom in Iran. J Venom Anim Toxins incl Trop Dis. 2013;19(3):21-9. [DOI:10.1186/1678-9199-193] [PMID] [PMCID]
10. Babaie M, Ghaempanah A. Evaluation of hemolytic activity and biochemical properties of Apis mellifera bee venom on NIH laboratory mice. J Neyshabur Univ Med Sci. 2020; 8(3):25-34.

11. Babaie M. Snakes venom proteins and coagulopathy caused by snakebite. J Birjand Univ Med Sci. 2020;27(4):1-11.

12. Yacoub T, Rima M, Karam M, Sabatier JM, Fajloun Z. Antimicrobials from venomous animals: An overview. Molecules. 2020;25(2402):1-19. [DOI:10.3390/molecules25102402] [PMID] [PMCID]

13. Almeida JR, Palacios ALV, Patiño RSP, Mendes B, Teixeira CAS, Gomes P3, et al. Harnessing snake venom phospholipases A2 to novel approaches for overcoming antibiotic resistance. Drug Dev Res. 2019;80(1):68-85. [DOI:10.1002/ddr.21456] [PMID]

14. Liu G, Yang F, Li F, Li Z, Lang Y, Shen B, et al. Therapeutic potential of a scorpion venom-derived antimicrobial peptide and its homologs against antibiotic-resistant gram-positive bacteria. Front Microbiol. 2018;9:1-14. [DOI:10.3389/fmicb.2018.01159] [PMID] [PMCID]

15. Malanovic N, Lohner K. Antimicrobial peptides targeting gram-positive bacteria. Pharmaceuticals (Basel). 2016;9(3):1-33. [DOI:10.3390/ph9030059] [PMID] [플

16. Chen CH, Lu TK. Development and challenges of antimicrobial peptides for therapeutic applications. Antibiotics. 2020;9(24):1-20. [DOI:10.3390/antibiotics9010024] [PMID] [PMCID]

17. Bahar AA, Ren D. Antimicrobial peptides. Pharmaceuticals (Basel). 2013;6(12):1543-75. [DOI:10.3390/ph6121543] [PMID] [PMCID]

18. Jenssen H, Hamill P, Hancock REW. Peptide antimicrobial agents. Clin Microbiol Rev. 2006;19(3):491-511. [DOI:10.1128/CMR.00056-05] [PMID] [PMCID]

19.Zolfagharian H, Mohajeri M, Babaie M. Bee venom (Apis Mellifera) an effective potential alternative to gentamicin for specific bacteria strains. J 
Pharmacopuncture. $\quad 2016 ; 19(3): \quad 225-30$. [DOI:10.3831/KPI.2016.19.023] [PMID] [PMCID]

20. Chen $\mathrm{Na}$, Xu S, Zhang Y, Wang F. Animal protein toxins: origins and therapeutic applications. Biophys Rep. 2018;4(5):233-42. [DOI:10.1007/s41048-0180067-x] [PMID] [PMCID]

21. Maehre HK, Dalheim L, Edvinsen GK, Elvevoll EO, Jensen IJ. Protein determination-method matters. Foods. 2018;7(1):1-11. [DOI:10.3390/foods7010005] [PMID] [PMCID]

22. Laemmli UK. Cleavage of structural proteins during the assembly of the head of bacteriophage T4. Nature. 1970;227:680-5. [DOI:10.1038/227680a0] [PMID]

23. Zolfagharian H, Mohajeri M, Babaie M. Honey bee venom (Apis mellifera) contains anticoagulation factors and increases the blood-clotting time. J Pharmacopuncture. 2015; 18(4):7-11. [DOI:10.3831/KPI.2015.18.031] [PMID] [PMCID]

24. Ahmed U, Mujaddad-ur-Rehman M, Khalid N, Fawad SA, Fatima A. Antibacterial activity of the venom of Heterometrus xanthopus. Indian $\mathbf{J}$ Pharmacol. 2012;44(4):509-11. [DOI:10.4103/0253-7613.99332] [PMID] [PMCID]

25. Munawar A, Ali SA, Akrem A, Betzel C. Snake venom peptides: Tools of biodiscovery. Toxins (Basel). 2018;10(11):1-29. [DOI:10.3390/toxins10110474] [PMID] [PMCID]

26. Perumal Samy R, Gopalakrishnakone P, Thwin MM, Chow TK, Bow H, Yap EH, Thong TW. Antibacterial activity of snake, scorpion and bee venoms: a comparison with purified venom phospholipase A2 enzymes. J Appl Microbiol. 2007;102(3):650-9. [DOI:10.1111/j.1365-2672.2006.03161.x] [PMID]

27. Talebimehrdar M, Madani R, Hajihosseini R, Moradi bidhendi M. Antibacterial activity of isolated immunodominant proteins of Naja Naja (Oxiana) Venom. Iran J Pharm Res. 2017;16(1):297-305.

28. Al-Asmari AK, Abbasmanthiri R, Abdo Osman NM, Siddiqui Y, Al-Bannah FA, Al-Rawi AM, et al. Assessment of the antimicrobial activity of few Saudi Arabian snake venoms. Open Microbiol J. 2015;9:1825. [DOI:10.2174/1874285801509010018] [PMID] [PMCID]

29. Zhao Z, Ma Y, Dai C, Zhao R, Li S, Wu Y, Cao Z, et al. Imcroporin, a new cationic antimicrobial peptide from the venom of the scorpion Isometrus maculates. Antimicrob Agents Chemother. 2009;53(8):3472-7. [DOI:10.1128/AAC.01436-08] [PMID] [PMCID]

30. Benli M, Yigit N. Antibacterial activity of venom from funnel web spider Agelena labyrinthica (Araneae agelenidae). J Venom Anim Toxin Incl Trop Dis. 2008;14:641-50. [DOI:10.1590/S167891992008000400007]
31. Ahmed U, Mujaddad-ur-Rehman M, Khalid N, Fawad SA, Fatima A. Antibacterial activity of the venom of Heterometrus xanthopus. Indian J Pharmacol. 2012;44(4):509-11. [DOI:10.4103/0253-7613.99332] [PMID] [PMCID]

32. Ciscotto P, Machado de Avila RA, Coelho EA, Oliveria J, Diniz C, Farias L, Carvalho M, et al. Antigenic, microbicidal and antipareasitic properties of an L-amino acid oxidase isolated from Bothrops jararaca snake venom. Toxicon. 2009;53:330-41. [DOI:10.1016/j.toxicon.2008.12.004] [PMID]

33. Jami al ahmadi A, Fathi B, Jamshidi A, Zolfagharian $H$, Zare Mirakabbadi A. Investigation of the antibacterial effect of venom of the Iranian snake Echis carinatus. Iranian J Vet Sci Technol. 2010;2(2):93-100. 